\title{
COVID-19 and hypopituitarism
}

\author{
Stefano Frara ${ }^{1} \mathbb{1} \cdot$ Paola Loli $^{1} \cdot$ Agnese Allora $^{1} \cdot$ Chiara Santini $^{1} \cdot$ Luigi di Filippo $^{1} \cdot$ Pietro Mortini $^{2} \mathbb{D}$. \\ Maria Fleseriu $^{3}\left[\right.$. Andrea Giustina $^{1}[$
}

Accepted: 6 July 2021 / Published online: 13 August 2021

(c) The Author(s), under exclusive licence to Springer Science+Business Media, LLC, part of Springer Nature 2021

\begin{abstract}
Besides the pulmonary manifestations caused by severe acute respiratory syndrome (SARS) coronavirus 2 (SARS-CoV-2), an emerging endocrine phenotype, which can heavily impact on the severity of the syndrome, has been recently associated with coronavirus disease 2019 (COVID-19). Patients with pituitary diseases or the pituitary gland itself may also be involved in COVID-19 clinical presentation and/or severity, causing pituitary apoplexy.

Moreover, hypopituitarism is frequently burdened by several metabolic complications, including arterial hypertension, hyperglycemia, obesity and vertebral fractures, which have all been associated with poor outcomes and increased mortality in patients infected by SARS-CoV-2.

This review will discuss hypopituitarism as a condition that might have a bidirectional relationship with COVID19 due to the frequent presence of metabolic comorbidities, to the direct or indirect pituitary damage or being per se a potential risk factor for COVID-19. Finally, we will address the current recommendations for the clinical management of vaccines in patients with hypopituitarism and adrenal insufficiency.
\end{abstract}

Keywords Hypopituitarism $\cdot$ COVID-19 $\cdot$ SARS-CoV-2 $\cdot$ Vaccination $\cdot$ Pituitary surgery

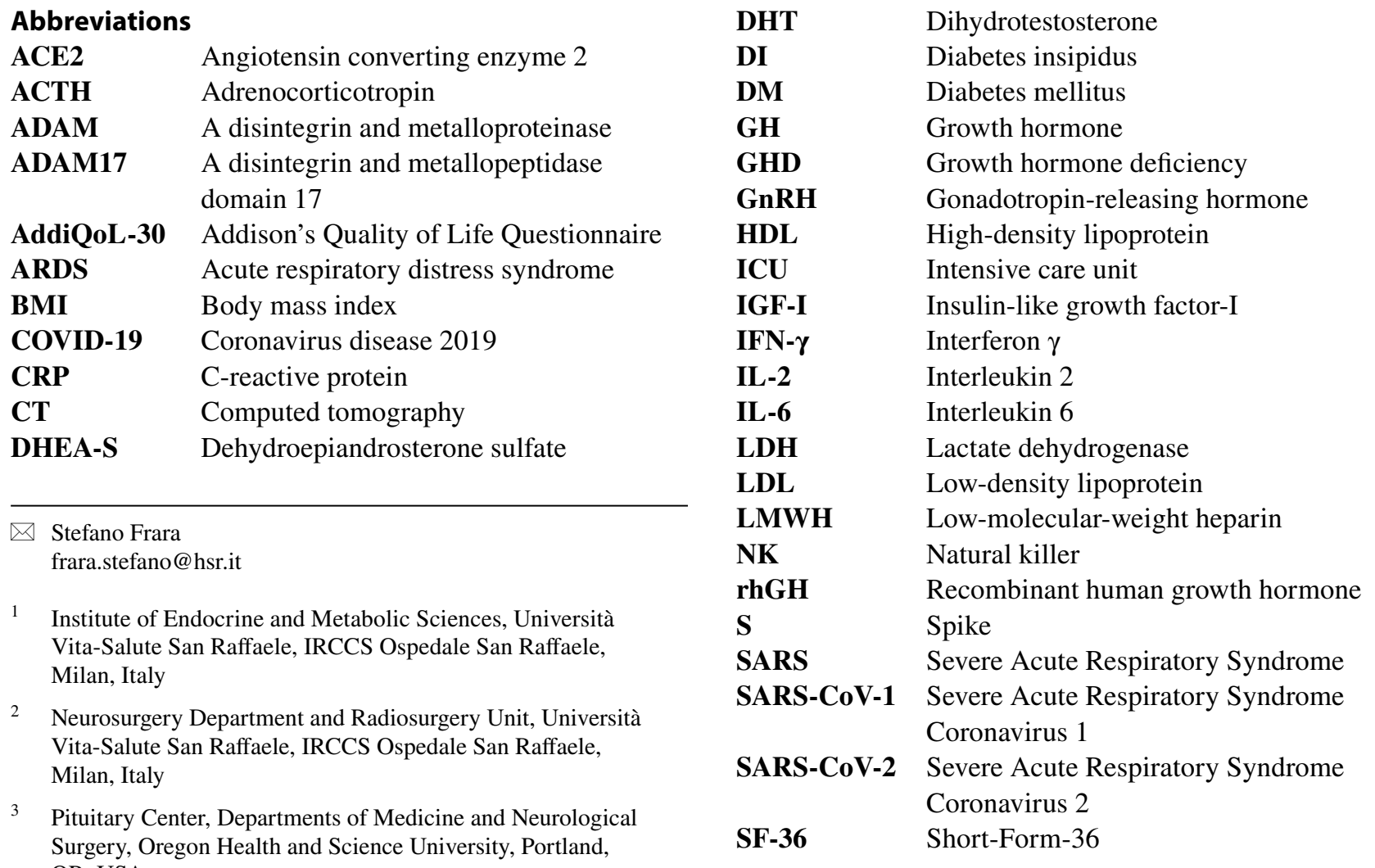




$\begin{array}{ll}\text { SHIM } & \text { Sexual Health Inventory for Men } \\ \text { TMPRSS2 } & \text { Transmembrane protease serine 2 } \\ \text { TNF- } \alpha & \text { Tumor necrosis factor- } \alpha \\ \text { TSH } & \text { Thyroid-stimulating hormone } \\ \text { VFs } & \text { Vertebral fractures }\end{array}$

\section{Introduction}

Coronavirus disease 2019 (COVID-19) was initially identified as a severe, potentially lethal respiratory infection, caused by severe acute respiratory syndrome (SARS) coronavirus 2 (SARS-CoV-2); presently, is characterized also by many relevant extra-pulmonary manifestations, including an emerging endocrine phenotype [1-3] which can heavily impact on the severity of the syndrome. Indeed, among those that experienced severe forms of SARS-CoV-2 or died for infections sequelae, a high prevalence of obesity, diabetes mellitus (DM), vitamin D deficiency and vertebral fractures (VFs) has been reported [4].

Interestingly, it has been recently reported that patients with pituitary diseases or the pituitary gland itself may also be involved in COVID-19 clinical presentation and/or severity [5]. In fact, pituitary apoplexy has emerged as possible feature of COVID-19, as well as patients with pituitary diseases may often have comorbidities such as DM and obesity, which can expose them to high-risk of severe COVID-19.

Our review will focus on hypopituitarism as a condition that might have a bidirectional relationship with COVID-19 due to the frequent presence of metabolic comorbidities, to the direct or indirect pituitary damage or being per se a potential risk factor for COVID-19. Paradigmatic case series collected during the pandemic at San Raffaele Hospital in Milan will be briefly reported. Finally, possible implications of hypopituitarism, including adrenal insufficiency in the context of COVID-19 vaccination will be discussed.

\section{Hypopituitarism and pituitary involvement in SARS-CoV-2 infection}

Hypopituitarism results from the failure of one or more pituitary hormones to be produced or released into the circulation by the pituitary gland, leading to specific systemic effects. Anterior pituitary failure is caused by several etiologic factors, including traumatic brain injury, sellar tumors, genetic mutations, infiltrative and infectious diseases [6].

The clinical manifestations are variable, depending upon the gender, the age of onset, the pituitary axes affected and the underlying comorbidities. The diagnostic approach is usually challenging, since it requires the assessment of the integrity of the various axes and dynamic testing is mandatory in the vast majority of the patients, as low peripheral hormones are associated with normal or slightly reduced pituitary hormones at baseline [7].
Early epidemiologic studies of patients with hypopituitarism demonstrated an excess standardized mortality ratio of 1.2-2.2 years, often ascribed to a higher incidence of cardiovascular and cerebrovascular events, with a more pronounced ratio in women [8]. Risk attributable specifically to hormonal replacement remains a controversial issue; however, updated studies reflect more contemporary replacement regimens, refinement of radiation and surgical treatment, and availability of more widespread and effective treatment for hormone replacement and comorbidities, such as arterial hypertension and hyperlipemia [9]. In these later studies devoted to assess mortality risk in patients with hypopituitarism treated with hormonal replacement, a normalization of mortality rate has been reported in most studies, but not all. Improvements have been seen particularly in patients with growth hormone (GH) deficiency (GHD) after GH replacement therapy [10].

Beyond the high expression on lung alveolar and small intestinal epithelial cells that explain the main pathogenic involvement of COVID-19 on respiratory and gastrointestinal systems [11], angiotensin converting enzyme 2 (ACE2) expression on cerebral tissues including endothelium, neurons and glial cells may play a role in SARS-CoV-2 neural invasion, as confirmed by COVID-19 neurological involvement in infected patients with headache, confusion, dysgeusia, anosmia, nausea and vomiting $[12,13]$. ACE2 mRNA expression has been reported in hypothalamus and pituitary gland cells [14] and confirmed in an autoptic study on pituitary tissues from patients who died from SARS [15].

Actually, SARS-CoV-2 entry into all host cells is mediated by the viral transmembrane spike (S) glycoprotein binding the metallopeptidase ACE2, that has been identified as the functional receptor for infection of SARS-CoV and SARS-CoV-2 mediating viral entry [16, 17], and then it can spread easily to many other target organs with its consequent pleiotropic manifestations [18].

\section{Risk factors of SARS-CoV-2 infection in patients with hypopituitarism}

There are many endocrine disorders that have been associated with poor COVID-19 outcomes and higher risk of death. At the same time, DM, obesity, hypertension and VFs are often found in patients with hypopituitarism, too (Fig. 1) [19-22].

DM rapidly emerged as one of the most frequent and clinically relevant comorbidities in hospitalized COVID-19 patients [23], but also mild hyperglycemia may have had a negative role in disease activity and outcomes [24]. Their exact mechanism is not well defined.

Through a direct action, SARS-CoV- 2 may enter $\beta$-cells through ACE-receptors inhibiting $\beta$-cells function, worsening hyperglycemia and increasing the risk for acute complications (i.e., ketoacidosis and hyperosmolarity). High-dose 
insulin requirement in patients with pre-existing DM has been linked to complications, but viral infection has been also associated as a cause of newly onset DM in previously non-diabetic subjects [25, 26].

Adults with hypopituitarism and GHD can develop hyperglycemia, which can even progress to overt DM, in contrast to children with GHD. This observation was particularly evident in the elderly and in female and/or obese patients [27]. Indeed, patients with GHD showed increased plasma insulin levels, both fasting and post-prandial.

Insulin-resistance was presumed by indirect evidence that GHD patients had reduced hepatic glycogen stores and later confirmed by hyperinsulinemic euglycemic clamps, showing reduced sensitivity of the peripheral tissues to insulin [28]. Moreover, this pronounced insulin-resistance is directly correlated with the percentage of fat mass and waist circumference [29]. Intriguingly, these metabolic alterations were reversible after few weeks of treatment with recombinant human $\mathrm{GH}(\mathrm{rhGH})$ at replacement dose, with amelioration in body composition parameters [30].

Obese patients are at increased risk for complicated COVID-19, high risk of hospitalization, increased need of invasive ventilation and admission in intensive care unit (ICU) [31], and related mortality [32], as confirmed by a recent meta-analysis enrolling more than 45.000 patients [33]. Moreover, altered body composition with increased visceral adiposity may negatively impact prognosis in subjects affected by COVID-19 [34].

A high total fat mass with greater deposition of visceral fat, an increased waist-to-hip ratio, together with a reduction in lean mass and body water (which leads to a reduction in cardiac preload) are highly prevalent features in adults with hypopituitarism and GHD [29]. These effects are strongly linked to the lack of GH action on intermediate metabolism, reducing the peripheral use of lipids as an energy substrate and the amino-acids available for protein synthesis [27].

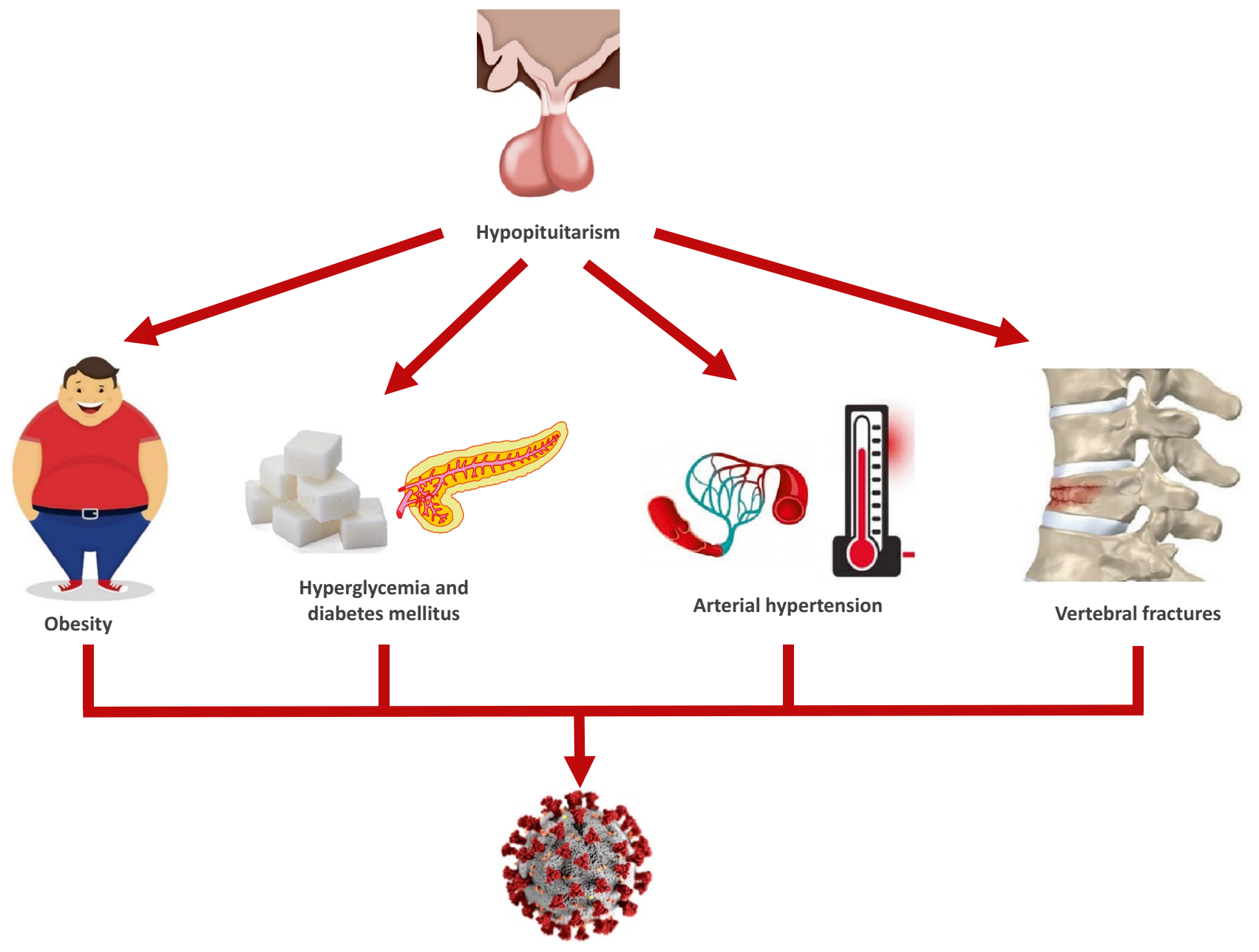

Fig. 1 Clinical risk factors for SARS-CoV-2 infection and COVID-19 severity associated with hypopituitarism. In particular, figure reports the impact of common comorbidities of hypopituitarism, such as obe- sity, diabetes mellitus, arterial hypertension and vertebral fractures on COVID-19 
Both obesity and altered body composition characterize several other pituitary disorders, such as Cushing disease [35] and acromegaly [36].

Interestingly, in patients with hypopituitarism, particularly those with untreated GHD and hypogonadism, cardiovascular risk per se is increased due to altered body composition with abnormal lipid profile and increased proinflammatory cytokines interleukin 6 (IL-6) and C-reactive protein (CRP) [37, 38].

Patients with cardiovascular disease have a higher COVID-19 mortality rate and poorer clinical outcomes [39, 40]. ACE2 is not only a SARS-CoV-2 receptor, but it has also an important homeostatic function regulating reninangiotensin system, which is pivotal for both the cardiovascular and immune system. Therefore, ACE2 seems to be the key link between SARS-CoV-2 infection, cardiovascular diseases and immune response [41]. Even if a lower ACE2 expression on cells surface has been observed in this subset of patients, a pathophysiological explanation is likely driven by the imbalance between a disintegrin and metalloproteinase (ADAM) domain 17 (ADAM17) protein (which is required for cleavage of ACE-2 ectodomain resulting in increased ACE2 shedding), and transmembrane protease serine 2 (TMPRSS2) (which is required for spike glycoprotein priming) [41].

It is well-known that cardiovascular major events are strictly correlated with dyslipidaemia [42]. Frequently, the first anomaly found in the biochemical evaluation of patients with hypopituitarism concerns the lipid profile: variable dyslipidaemias develop, with an increase in triglycerides and low-density lipoproteins (LDL) in both genders; the reduction of high-density lipoprotein (HDL) is found most prevalently in women. Patients with GHD have additionally a change in LDL molecules composition, which are denser and smaller than in the general population, worsening their negative effects on endothelium [37]. This increase in atherosclerotic processes leads to an increased risk not only for acute major events such as myocardial infarction, brain ischemia or transitory ischemic attack, but also for chronic diseases, including chronic ischemic heart disease and chronic cerebral vasculopathy [43].

Patients with hypopituitarism, and in particular those with untreated GHD, are considered, for all these reasons, at high cardiovascular risk [37]. Previous studies on rhGH replacement therapy confirmed the positive effects on these regards, with a reduction of the atherogenic pattern (i.e., reduction of total and LDL-cholesterol together with an increase in serum HDL-cholesterol) and the normalization of proinflammatory markers [44].

Arterial hypertension, another component of the metabolic syndrome, was highly prevalent in patients with severe SARS-CoV-2, accounting for almost $20 \%$ of all the patients with acute respiratory distress syndrome (ARDS) [45] and mortality rate was significantly increased in hypertensive patients.

Several studies have argued that GH and insulin-like growth factor-I (IGF-I) play a role in the regulation of peripheral resistance, although it is difficult to distinguish the direct effects of the former [46] and those mediated by the latter [47]. Both hormones can reduce peripheral resistance with an increase in blood flow, promoting the release by the endothelium and the vasodilating action of nitric oxide [48]. Arterial hypertension is a common finding in adults with GHD and most of the studies showed that rhGH treatment was effective in reducing blood pressure, even though it is still debated the quantification of peripheral resistance reduction. In this regard, the age at onset represents a protective factor for those with child-onset GHD as compared to those whose deficiency arose in adulthood [49].

Based on these data, metabolic syndrome seems to be not only a risk factor for cardiovascular events, but also highly prevalent in patients with hypopituitarism and significantly associated with severe cases and a higher mortality in COVID-19 patients. The presence of only one metabolic syndrome component doubles the risk of death by COVID19 (OR 1.83; 95\%IC 1.77-1.89), which was even higher among patients with DM plus hypertension (OR 2.22; 95\% IC 2.15-2.28) and becoming three-times higher in those with all four diagnostic criteria (OR 3.36; 95\%IC 2.83-3.99) [50].

Performing a morphometric VF assessment in more than 100 COVID-19 patients, thoracic morphometric VFs were highly prevalent, affecting about one third of all cohort [51] and correlated with the mortality rate, which was doubled as compared to non-fractured patients [51].

Based also on our previous manuscripts where we observed a high prevalence and incidence of morphometric VF in patients with heart failure [52, 53], we have hypothesized that VFs may represent a sensitive clinical marker of frailty in SARS-CoV-2 patients and a predisposing factor to negative pulmonary outcomes in the disease [51]. In fact, VFs are associated with an increased risk of pneumonia and impaired respiratory function also in patients without previous chronic respiratory disorders [54-56].

Interestingly, patients with GHD have a reduction in bone turnover, exposing them to a high risk for osteoporosis [57]. Due to the simultaneous impairment of both osteoclastogenesis and osteoblastogenesis, significant alterations in bone microarchitecture has been previously highlighted, with a greater bone loss in cortical bone [58]. Indeed, prevalent VFs were found in one third of patients with hypopituitarism independently from gender [59]. Moreover, in hypopituitarism an increased incidence of VFs was also reported [60].

Patients with diabetes insipidus (DI) during significant illness have difficulties maintaining their fluid balance [61]; hypernatremia has been linked to increased mortality in those admitted to intensive care units [62]. 


\section{COVID-19 as a cause of pituitary apoplexy and hypopituitarism}

Pituitary apoplexy is an acute clinical and surgical emergency syndrome due to a sudden haemorrhage and blood infarction of the pituitary gland, typically within a pituitary macroadenoma [63]. Main symptoms referred by patients have a sudden onset and include severe headache, impaired visual field and ocular palsy, due to tumor haemorrhagic and necrotic mass compressing the surrounding optic structures and expanding into the cavernous region [64]; hypopituitarism is a frequent consequence in this clinical setting due to the massive destruction of the pituitary gland.

Pituitary apoplexy is usually a rare event (incidence $0.17 / 100^{\circ} 000$ /year and prevalence $6.2 / 100^{\circ} 000$ ) occurring in up to $12 \%$ of patients with pituitary adenoma [64], particularly in those with concomitant anticoagulant treatment [65] or in prolactinomas starting dopamine-agonists [66, 67].

Previous autoptic and radiological studies have shown a possible relationship with viral infectious diseases, such as the hemorragic fever, direct pituitary vascular damage with ischemic and hemorrhagic signs, and foci of necrosis [68, 69]. Moreover, an increased stimulation of the pituitary gland, as occurs in an infectious stress state, may increase pituitary blood demand precipitating acute apoplexy [69].

COVID-19 has been recently highlighted as a plausible precipitating risk factor for pituitary apoplexy (Fig. 2), based on some case reports, most of them in patients with concomitant pre-existing macroadenomas [70-73]. A possible pathophysiological explanation may be derived from the evidence of multiple events of thrombocytopenia, coagulopathy, and platelet dysfunction, due to ACE2 expression in cerebral vascular endothelium [74]. Additionally, it has been hypothesized that the virus may enter the brain through the nasopharyngeal epithelium via the olfactory nerve, could pass the blood-brain barrier or directly through the median eminence, which lacks of the blood-brain barrier [74]. Therefore, COVID-19-related prothrombotic and endothelial systemic illness may be precipitating risk factors for pituitary apoplexy, especially in patients affected by pituitary adenomas, in particular those treated with anticoagulant therapy or those harbouring a PRL-secreting macroadenoma on dopaminergic agents.

Taking into account the rarity of this disorder, the link between COVID-19 and pituitary apoplexy is only putative at present time and the emerging of this condition may also derive from a selection bias, resulting from the referrals to neurosurgeons only of acute conditions [75]. Actually, several case reports have been published, describing paucisymptomatic patients in most of the cases. Based on available evidences, it can be assumed that the severity of the disease is not different from the general population; however, the management might be more challenging due to surgical procedure, sudden onset of pituitary hormonal failure and adequate replacement therapies.

Chan et al. reported a case of pituitary apoplexy in a third trimester pregnant woman complicated by COVID-19 [70] in whom endocrine biochemical work-up showed low gonadotropins and thyroid-stimulating hormone (TSH), together with increased serum prolactin levels and consequently levothyroxine and hydrocortisone replacement therapy was initiated [70].

Solorio-Pineda et al., reported the case of a 27-year-old male hospitalized with severe COVID-19 [73] in whom brain computed tomography (CT) scan showed a heterogeneous hemorragic tumoral sellar lesion with likely secondary hypogonadotropic hypogonadism.

In two other cases with pituitary apoplexy and COVID19 , secondary adrenal insufficiency was found and in one of them subsequent central hypothyroidism developed; hydrocortisone three times a day as well as levothyroxine were started. Interestingly, in this latter case the only precipitating factor was COVID-19 infection [76]. Of the remaining three cases reported with this interesting clinical association, either no or normal hormonal data were reported.

\section{SARS-CoV-2 infection in patients with hypopituitarism}

\subsection{Adrenal insufficiency}

Patients with adrenal insufficiency have double mortality rate compared to general population, due to high cardiovascular and infection risk [77]. In this specific setting, acute respiratory events could be serious in most of the patients, due to altered immune response with reduced cytotoxic function of natural killer (NK) cells [78], with a significant increased number of hospitalization [79] and ICU admission (Fig. 3) [80]. Nonetheless, one could argue that increased hospital admissions could be also related to a greater awareness of the adrenal crisis risk during acute events [81, 82], in particular for those patients managed in center of excellence for pituitary disorders where educational courses are provided [83, 84].

Importantly, patients with adrenal insufficiency may be at high risk of overtreatment, since established glucocorticoid replacement regimens do not completely reproduce the endogenous hormonal production and reliable clinical and biochemical markers are lacking [85], with consequent increased risk for DM, obesity, hypertension and chronic inflammatory disease, all conditions currently recognized as risk factors for poor outcomes and death in COVID-19 [3, 21].

However, both dexamethasone and methylprednisolone may exert some beneficial effects [86] while inhibiting viral entry into cells by binding to ACE2 [87]. It could be argued 


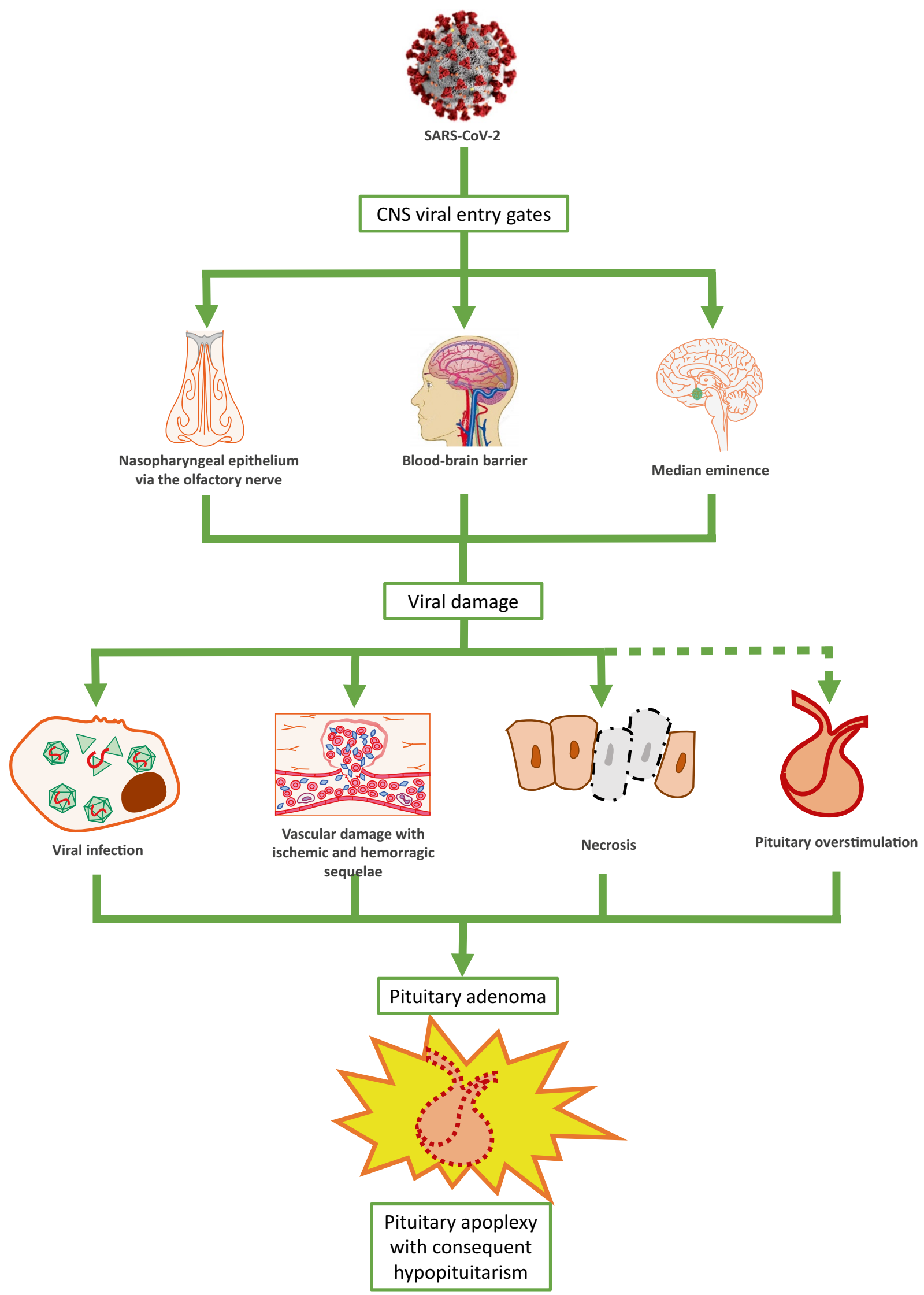


4Fig. 2 Pathophysiological mechanisms of pituitary apoplexy and hypopituitarism in COVID-19. In particular, the figure describes the different types of SARS-CoV-2 damage ranging from viral infection per se to vascular damage or pituitary cells overstimulation, potentially causing pituitary apoplexy

that the prolonged use of high-dose exogenous glucocorticoids (also depending on daily dose, duration of treatment and individual sensitivity to the drug) may result in suppression of hypothalamic-pituitary-adrenal axis, causing a consequent condition of adrenal insufficiency [88]. In point of fact, in previous SARS pandemic, high prevalence $(40 \%)$ of transient central (secondary) adrenal insufficiency was described in 61 patients survived at Severe Acute Respiratory Syndrome Coronavirus 1 (SARS-CoV-1) infection, with a restore of pituitary-adrenal function within one year [89].

A recent study performed on 28 consecutive patients with COVID-19 and no previous history of pituitary insufficiency, confirmed this finding. Alzahrani AS et al. revealed that the adrenocortical response, tested performing morning plasma cortisol, adrenocorticotropin (ACTH) and dehydroepiandrosterone sulfate (DHEA-S) levels in patients with COVID19 was impaired and a significant percentage of the patients had plasma cortisol and ACTH levels consistent with central adrenal insufficiency [90].

In a retrospective study with telephone interviews on 279 patients with primary or secondary adrenal insufficiency referring to an Italian tertiary centre [88], no significant differences in prevalence of symptoms suggestive for COVID-19 were reported as compared to 112 controls with benign pituitary lesions and normal pituitary function ( $24 \%$ and $22.3 \%$, respectively). Furthermore, no differences between primary and secondary adrenal insufficient subgroups were observed and there were no cases of adrenal crisis or hospitalization [88]. It must be acknowledged that the exact prevalence of SARS-CoV-2 infection was unknown, since availability of testing in the first pandemic wave was particularly limited (12 subjects, only underwent the test and most of them were actually negative).

Authors observed a longer duration of highly suggestive symptoms and higher prevalence of gastrointestinal symptoms in controls than in patients with adrenal insufficiency who adopted more rigorous behaviours, due to the detailed instructions received for the management of infectious complications. Moreover, it was speculated that cytokine release in the gastrointestinal tract could have been mitigated in patients under chronic glucocorticoid treatment [88].

In another Italian monocentric cross-sectional study covering the first pandemic wave, 121 patients with adrenal insufficiency (40 primary, 81 secondary) completed telematically three questionnaires: the purpose-built
“CORTI-COVID”, assessing medical history and concern for COVID-19-related global health, hypocortisolismspecific personal health, occupational, economic, and social consequences; the Addison's Quality of Life Questionnaire (AddiQoL-30) and the Short-Form-36 (SF-36) Health Survey. In this CORTI-COVID study, SARS-CoV-2 was experienced by one middle-aged patient, only $(0.8 \%)$ who promptly tailored her replacement therapy. Dyspnea lasted three days, without requiring hospitalization. In addition, no adrenal crises were reported, but pandemic-related stress accounted for 6/14 glucocorticoid up-titrations. No differences were observed amongst primary and secondary adrenal insufficiency; whereas survey results showed concerns regarding patients' personal health and economic status, confirming that even under unconventional stress, adequately trained patients preserve a good quality of life [91].

In an English single-center study on 412 patients with pituitary diseases, few patients were infected and no deaths due to COVID-19 were identified [92]. However, 267 patients experienced a delay or change in the planned care for their pituitary disease, with 100 patients perceiving an impact to their care [92]. A prospective longitudinal survey on 342 patients with adrenal insufficiency (109 with secondary and 76 with glucocorticoid-induced) did not show changes in daily glucocorticoid dose or number of adrenal crises when compared to prepandemic, but patients reported a higher financial impact from adrenal insufficiency and difficulty accessing medical care during the pandemic. Specifically, a third of patients with adrenal insufficiency reported difficulties with management of adrenal insufficiency during the pandemic, particularly in younger patients, women, and those with poor healthcare access [93]. This highlights the importance of continued regular care to patients with pituitary disorders and other rare chronic diseases, as impact could be more severe than the COVID risks per se.

\subsubsection{Personal case series}

These previous findings of a mild COVID-19 in hypoadrenal subjects infected with SARS-CoV-2 is substantially confirmed by three of our cases of hospitalized patients with hypopituitarism and documented adrenal insufficiency (Table 1) [94]. An 80-yr-old patient with hypopituitarism and DI after surgery for craniopharyngioma several years before tested positive for SARS-CoV-2 at hospital admission for cardiogenic syncope. He had hypertension, mild DM, chronic obstructive pulmonary disease, atrial fibrillation, vascular disease; he was on stable therapy with levothyroxine, high daily doses of cortisone acetate $(62.5 \mathrm{mg} /$ day $)$, intranasal desmopressin and anticoagulants. He had neither symptoms nor radiological signs specific for COVID-19. Blood tests showed moderate 
Fig. 3 Possible contribution of deficient pituitary-target gland axes to susceptibility to SARSCoV-2 infection in hypopituitarism. In details, the figure illustrates the role of specific components of hypopituitarism, including hypogonadism, GH deficiency and adrenal insufficiency, possibly predisposing to SARS-CoV-2 infection and severe COVID-19

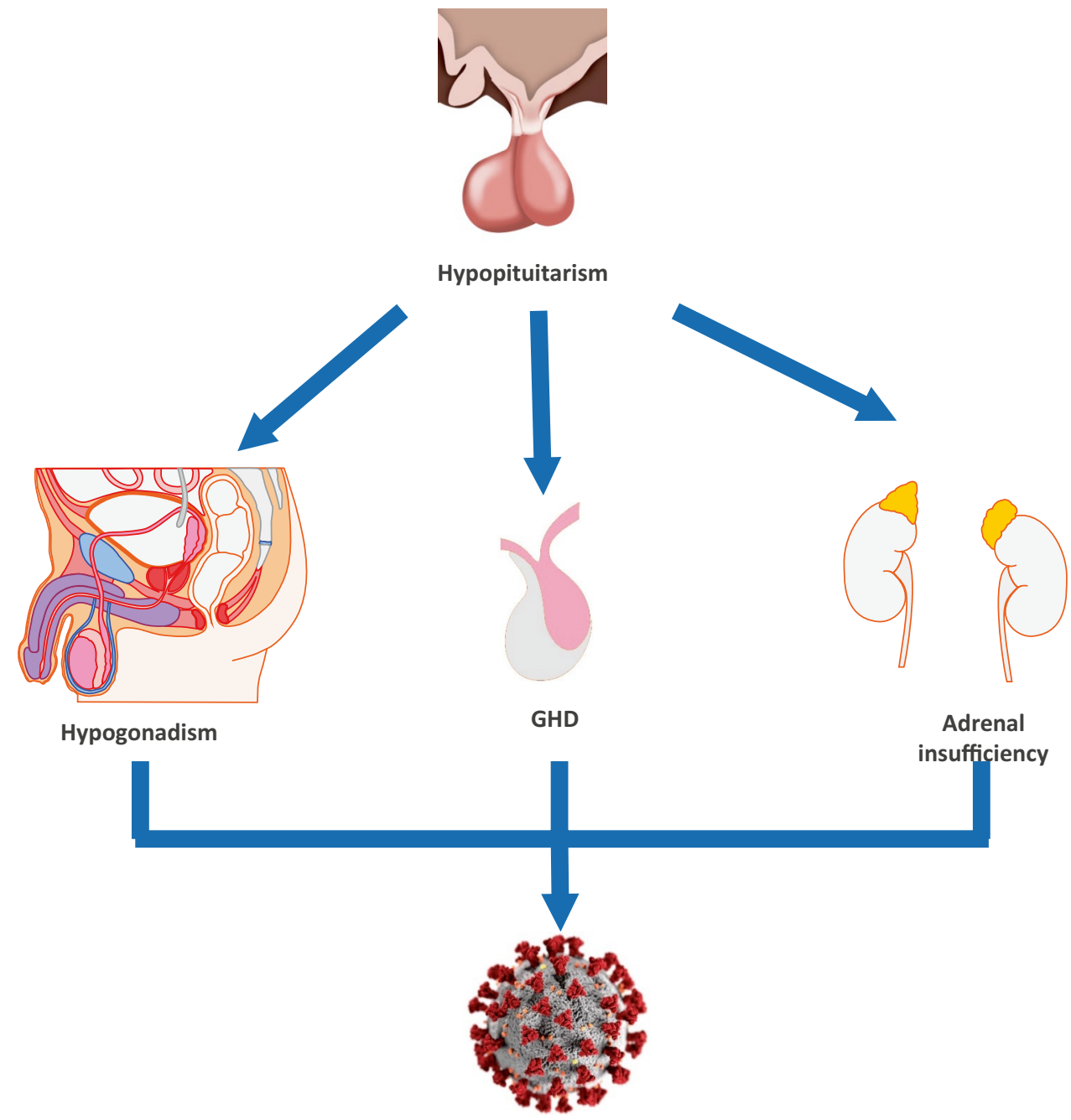

hyponatremia and increased lactate dehydrogenase (LDH), CRP, IL-6 and D-dimer. He received a supplemental dose of parenteral hydrocortisone, optimization of desmopressin and no specific therapy for COVID-19. He was discharged after pacemaker placement.

The second patient was an 18-yr-old male with hypopituitarism after surgery for craniopharyngioma at 12-yo, severe obesity [body mass index (BMI) 49.5] and DI; he was on stable therapy with levothyroxine, hydrocortisone $(25 \mathrm{mg} /$ die), desmopressin, testosterone and rhGH. He presented to the emergency room with fatigue and drowsiness, but no respiratory symptoms; and tested positive for Sars-CoV-2. Chest X-rays showed an increase of vascular pattern in both lungs. Blood tests showed increased CRP, normal IL-6 and D-Dimer. He received antibiotic therapy and prophylactic anticoagulant coverage with low-molecular-weight heparin (LMWH); oral hydrocortisone dose was doubled. No respiratory complications occurred and the patient was discharged 3 days later.
Finally, a 78-yr-old male patient with hypopituitarism after surgery for suprasellar arachnoid cyst on stable therapy with levothyroxine, cortisone acetate $(25 \mathrm{mg} /$ day), testosterone and rhGH presented to the emergency room with cough, dyspnea and fever for one week. He tested positive for SARS-CoV-2; chest CT showed COVID-19-associated pneumonia. Inadvertently, cortisone acetate therapy was missed for $40 \mathrm{~h}$ while staying at the hospital. Blood tests showed moderate hyponatremia, and increased LDH and CRP. He received low-flux oxygen, ritonavir/lopinavir and hydroxychloroquine. His clinical conditions significantly improved and he was discharged after 6 days.

Onset of adrenal failure has been also described in a patient with Cushing disease due to a relapsing ACTH secreting pituitary macroadenoma and COVID-19 pneumonia on treatment with metyrapone and cabergoline. In this specific case, enoxaparine was used to control the hypercoagulable state and might have represented a potential confounding factor in the genesis of persistent hyperkalemia 


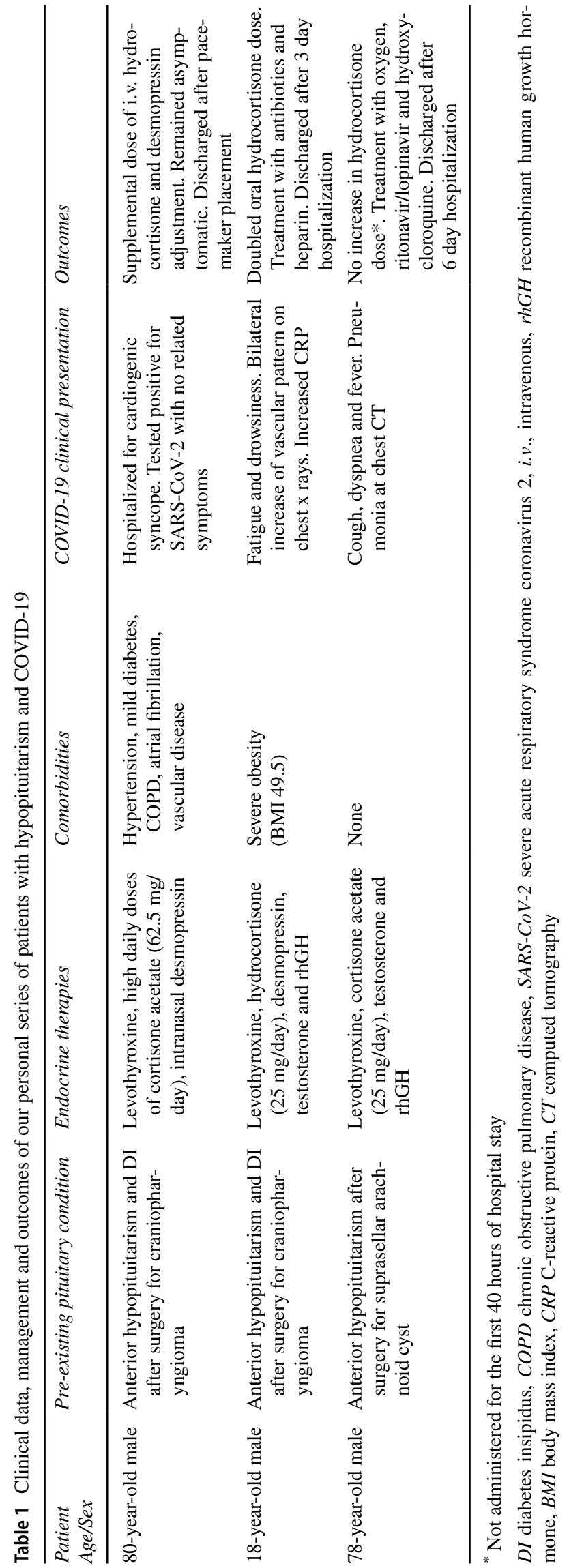

after correction of adrenal insufficiency, due to suppressive effect on aldosterone production [95].

Based on these preliminary publications, it could be hypothesized that albeit at high risk, the susceptibility of patients with adrenal insufficiency at SARS-CoV-2 infection is still uncertain, but those who are adequately treated and trained have not shown poorer clinical outcomes or higher risk for death.

Recommendations for the prevention of Addisonian crisis must be carefully followed both by the patients and the clinicians, increasing the oral daily doses in case of asymptomatic disease or mild form, and switching to parenteral glucocorticoids (preferably hydrocortisone) for those with moderate-severe clinical manifestations [96, 97]. Moreover, hydration and electrolytes replacement still represent a cornerstone in the management of acute events in patients with adrenal insufficiency and, in particular, in those with concomitant DI, where fluid loss and electrolyte abnormalities frequently occurs, especially if fever, tachypnea, diarrhoea and/or vomiting are present [98].

\subsection{Hypogonadism}

Epidemiological studies clearly showed a male preponderance and age-dependent susceptibility to the severity of SARS-CoV-2, with young female predominantly experiencing a milder disease. More in detail, a retrospective, observational Italian study conducted on 431 consecutive enrolled adult patients, observed that women were a minority $(27.6 \%$ of the total cohort) and overall 28-day mortality was significantly lower in women than in men $(26.1 \%$ vs. $38.1 \%$, respectively). Gender did not result an independent predictor of death once the parameters related to disease severity at presentation were included in the multivariable analysis. Authors concluded that hospitalized women were less likely to die from COVID-19; however, once severe disease occurs, the risk of dying is similar to men [99].

Erectile dysfunction has been recently investigated as a potential early marker of high cardiovascular risk [100]. In fact, males with hypogonadism are more frequently affected by metabolic syndrome and erectile dysfunction was associated with older age, obesity, ischaemic disease and unhealthy lifestyle habits [101]. Indeed, most of these conditions were associated with poorer clinical outcomes, increased hospitalization, ventilation and mortality in COVID-19 infection. Furthermore, an Italian group reviewed data coming from the "Sex@COVID" online survey, aiming at retrieving a sample of Italian male sexually active subjects with reported SARSCoV-2 infection and comparing their results with COVID19-negative male sexually active subjects, using propensity score matching in a 3:1 ratio. The prevalence of erectile dysfunction, measured with the Sexual Health Inventory for Men (SHIM), was significantly higher in the COVID + group (28\% 
vs. $9.33 \% ; p=0.027)$ and logistic regression models confirmed a significant effect of COVID-19 on the development of erectile dysfunction, independently of other variables affecting erectile function, such as psychological status, age, and BMI. Likewise, subjects with erectile dysfunction were more likely to have COVID-19, once corrected for age and BMI [102].

Reported data from different European countries suggest contradictory outcomes when considering hypogonadism. Low testosterone and dihydrotestosterone (DHT) levels were observed in the majority of COVID-19 intensive care patients [103], whereas low total and free testosterone levels $(<5 \mathrm{nMol} / \mathrm{L}$ and $<100 \mathrm{pMol} / \mathrm{L}$, respectively) predicted poor prognosis and mortality [104]. The majority of COVID-19 men presented low testosterone (68.6\%) and DHT (48.6\%) levels. In contrast, most female COVID-19 patients have elevated testosterone levels (60\%) without alterations in DHT levels. Both COVID-19 females and males had elevated estradiol levels (40\% and $45.7 \%$, respectively) [103]. In male COVID-19 patients, testosterone levels negatively correlate with inflammatory interleukin 2 (IL-2) and interferon- $\gamma$ (IFN- $\gamma$ ), whereas estradiol levels positively correlate with the inflammatory cytokine IL-6. Vice versa, in COVID-19 women, testosterone levels positively correlate with inflammatory cytokines [103].

While both studies have limitations such as lack of control groups or testosterone levels prior to infection and one was not peer-reviewed, they highlighted the role of gonadal status in COVID-19 (Fig. 3). These outcomes should be also analysed taking into account that serum testosterone levels physiologically drop in the elderly, so the association between hypogonadism and poorer outcomes and higher mortality may reflect the well-demonstrated correlation between age and disease severity.

Recent studies tried to move forward, analysing the risk for COVID-19 in patients with androgenic alopecia and prostate cancer, conditions that have been strictly correlated to androgen sensitivity more than androgen levels. Actually, data seems inconclusive so far [105]: androgenic alopecia was observed in many hospitalized patients and was shown as an independent risk factor for developing severe COVID-19 symptoms [106, 107].

Conversely, prostate cancer patients under androgen deprivation therapy seem to have a lower risk of COVID-19 infection compared to cancer patients not-undergoing gonadotropinreleasing hormone $(\mathrm{GnRH})$-analogues and/or peripheral androgen antagonists (OR 4.05; 95\%CI 1.55-10.59). Intriguingly, a greater difference was also found comparing prostate cancer patients receiving androgen deprivation therapy and patients with any other type of cancer (OR 4.86; 95\% CI 1.88-12.56) [108], albeit patients with prostate cancer under androgen deprivation therapy are at high risk for fragility fractures, a recentlyobserved negative prognostic factor for COVID-19 [109].

Considering hypogonadism in a hypothalamic-pituitarycentered view, one could argue that in a non-negligible number of patients infected by SARS-CoV-2, especially in those patients with paucisymptomatic disease, anosmia and ageusia can represent the first or even the only symptom [110]. Recent studies have suggested that ACE2 receptors are strongly expressed on the nasal mucosa, suggesting that SARS-CoV-2 might exert a toxic action on the multiple central nervous system's sites, including the olfactory bulb and the hypothalamus [111]. Moreover, the relationship between anosmia and hypogonadism as observed in the Kallmann syndrome is well-established in literature. At present time, there are no data on possible COVID-19-associated hypogonadotropic hypogonadism, but this link should be adequately addressed in the future, taking into account also that erectile dysfunction has been described as a possible sequelae in COVID-19 survivors who experienced anosmia and ageusia [112].

Based on the aforementioned evidence, Brandi \& Giustina suggested sex-specific recommendations in the comprehensive management of patients infected by SARSCoV-2, adjusting testosterone replacement doses in men with the aim to avoid pro-inflammatory responses of hypogonadism and, at the same time, avoiding overtreatment with possible increased risk for venous thromboembolism related to the hematocrit increase. For the same reason, oral contraceptives prescription should be individualized, probably preferring those formulations with lower thromboembolic risk or opting for other medical devices. Notably, hormonal replacement therapies should be continued both in post-menopausal women (when appropriate) and in those with pre-menopausal hypogonadism [20].

\subsection{GHD}

Adult patients with GHD may have several metabolic abnormalities such as altered body composition including obesity and sarcopenia [113], hypertension, hyperglycemia or overt DM and, finally, an increased cardiovascular risk (described above as risk factor for poor clinical outcomes in COVID-19) (Fig. 1) [114, 115], exposing them to higher risk for COVID-19 (Fig. 3). Noteworthy, decreased GH levels are a common denominator in the elderly and particularly in males; at the same time the susceptibility of COVID-19 infection has been reported to be age- and sex-dependent [116].

Moreover, it is well known that lymphoid organs and peripheral blood cells produce $\mathrm{GH}$ and, at the same time, GH receptor is expressed on different subpopulations of lymphocytes. Many in vitro and in animal studies demonstrated an important role of $\mathrm{GH}$ in immunoregulation. GH stimulates $\mathrm{T}$ and $\mathrm{B}$ cells proliferation and immunoglobulin synthesis, enhances the maturation of myeloid progenitor cells and is also able to modulate cytokine response. 
However, in humans GHD has not clearly been associated with immunodeficiency and only minor abnormalities of immune function have been reported [117]. Elevated baseline tumor necrosis factor- $\alpha$ (TNF- $\alpha$ ) and IL- 6 as well as impairment in fibrinolysis have been suggested as putative causes of increased cardiovascular risk in patients with GHD and improvement of all these parameters (together with pro-inflammatory markers reduction) has been observed after rhGH replacement therapy, highlighting potential inhibitory effects on inflammation as well as normalization of the fibrinolytic system [118].

There are actually no data on GHD and prevalence of COVID-19, as well as possible systemic complications or severity of the disease. However, we know that amongst the daily difficulties remains a relevant clinical question the treatment adherence and, consequently, its impact, on clinical outcomes of GHD patients. Collecting data from online and telephone survey on parents of 107 paediatric patients affected by GHD, the majority of patients $(>80 \%)$ remained highly adherent to replacement therapies even during pandemic. The main reason for nonadherence was related to drug supply issues, with some missed injections [119]. These percentages were actually similar to (or even higher than) previous ones reported before the onset of COVID-19 pandemic, where up to $72 \%$ of paediatric, adult or in-transition patients had an acceptable adherence to GH replacement therapy [120, 121].

To justify these surprising results, the authors leading the survey hypothesized that home confinement due to COVID-19 pandemic might be a possible explanation for the unexpectedly high adherence rate despite the disruption of clinical care for most of the patients [119].

\subsection{Diabetes insipidus}

Patients with DI admitted to the hospital with COVID-19 have a high mortality risk due to volume depletion and thus endocrinologists must supervise fluid replacement and dosing of desmopressin. Many electrolyte imbalances have been described in patients with COVID-19, hyponatremia being the most frequent sodium abnormality. However, there have been also reports of idiopathic central DI during severe COVID-19 [122] or its recovery [123].

Possible mechanisms entertained for central DI are inflammation-mediated reversible hypophysitis in the setting of severe ARDS, direct immune-mediated damage or poor prognosis in itself.

Dehydration and hypernatremia could also contribute to the high risk of acute kidney injury in COVID-19. In patients with severe COVID-19, caution is needed when replacing intravenous fluids due to high risk of pulmonary edema in these patients. Lack of access to serial laboratory work-up during pandemic, usually needed frequently for patients with adipsic DI associated with hypothalamic disorders, represents a major impediment which can affect outcomes.

Furthermore, these patients with adipsic DI frequently have hypothalamic obesity and thus require special attention during COVID-19, as both could represent risk factors for poor outcomes in patients with COVID-19.

The most complicated management is those of patients with both adrenal insufficiency and DI, as fluid and electrolyte disorders are frequent with COVID-19; monitoring and cautious water and electrolyte replacement to avoid both hyponatremia and hypernatremia are needed in these complex patients with panhypopituirarism.

In a large population matched cohort study, patients with hypopituitarism were highly vulnerable once hospitalized for acute medical conditions [80] with increased risk of mortality and adverse clinical outcomes [124]. This was most pronounced among those with DI. Patients admitted to the hospital with fever and tachypnea, especially if they have altered level of consciousness should be placed on strict intake and output measurements to match output.

Delaying desmopressin dose once a week will allow excess retained water to be excreted and body weight should be measured by patients daily [61].

As recommended even pre-pandemic [98], all patients with central DI admitted to the hospital with COVID-19 should be co-managed with endocrinology consultants. An alert system for desmopressin would be beneficial, both to reduce prescribing errors, and to ensure that this essential drug not get discontinued and just adjusted.

We are pleased that endocrine-related targets represent now the vanguard of COVID-19 research and more is yet to come about ending this pandemic, hopefully in the near future.

\section{COVID-19 vaccination and pituitary diseases}

Published data on the effectiveness of the vaccine against COVID-19 have not reported adverse events or particular contraindications in relation to pituitary diseases and hypopituitarism [125]. The two studies conducted on the mRNA1273 SARS-CoV-2 and mRNA BNT162b2 COVID-19 vaccines showed no increased prevalence of adverse events or less efficacy of the vaccine in the subpopulation of patients suffering from DM or obesity $[125,126]$, which represent the most common complications in patients with hypopituitarism.

Some concerns regarding the efficacy of vaccine in patients under glucocorticoid therapies has been arisen, since the publication of an unpeer-reviewed manuscript in which Authors observed an impaired SARS-CoV-2 vaccineinduced immunity in patients with chronic inflammatory diseases under immunosuppressive therapies, with 
glucocorticoids and B cell depletion therapy more severely impeding optimal responses [127].

Nonetheless, daily glucocorticoid doses for rheumatic and chronic inflammatory treatment are undoubtedly higher than those prescribed as replacement therapies. Moreover, in the past years, prednisone bursts did not diminish the response of asthmatic children to the 1996 influenza virus vaccine, compared with controls. Children can be effectively vaccinated against influenza virus while they are receiving prednisone therapy bursts for asthmatic exacerbations [128].

The vaccines can give moderate-to-severe systemic side effects such as fever, fatigue, myalgia, arthralgia, and headache $[125,126]$. In this regard, the Pituitary Society surveyed their members and recently published a statement on the management of glucocorticoid therapy in patients with adrenal insufficiency preparing for vaccinations. Of the 103 respondents, around one third indicated would automatically increase the glucocorticoid dose upon vaccination in their patients, particularly on the day of the vaccine administration, but some also prior to the vaccination. The majority of endocrinologists planned to maintain unchanged the glucocorticoid dose in patients with adrenal insufficiency undergoing vaccination, with most of them planning to increase glucocorticoid dose only if side effects, especially if fever, but also arthralgia and myalgia were going to occur [129].

COVID-19 vaccine remains, in conclusion, the only available "good" fight against SARS-CoV-2 and vaccine access must be guaranteed to all, including those fragile people at high risk for severe or even lethal COVID-19, like patients with hypopituitarism.

\section{Follow-up care; pandemic and its aftermath}

More than a year and a half in the pandemic, regular clinical services for patients with pituitary disease are still reduced worldwide [130]; these delays in both diagnosis and treatment plans could have significant impact on patients' outcome, morbidity, quality of life and mortality. Telemedicine has been playing an important role, but new management algorithms incorporating intertwined virtual and clinical care are needed. This will likely be very different depending on health care systems and virus load. Stratifications based on risks for COVID-19 in the absence of vaccinations, but also risk of untreated pituitary disease per se should be evaluated.

\section{Conclusions}

Hypopituitarism may expose to higher risk of COVID-19, due to coexisting metabolic derangements such as DM, obesity and VFs. Moreover, lack of pituitary hormones may negatively impact on the susceptibility to SARSCoV-2 infection and on outcome of COVID-19. Furthermore, SARS-CoV-2 infection may damage directly or indirectly the pituitary, inducing vascular events and causing loss of pituitary function. Due to the rarity of the disease, clinical evidences reported so far are too scanty in order to draw definitive conclusion on this bidirectional relationship of COVID-19 and hypopituitarism. Registries collecting real world data in pituitary patients affected by COVID-19 are needed to better define the dimension and the clinical relevance of this relationship. Finally, hypopituitarism is not a contraindication to COVID-19 vaccination, although careful management of glucocorticoid treatment may be needed in patients with hypodrenalism and vaccine side effects.

Funding No funds, grants, or other support was received for conducting this study.

\section{Declarations}

Ethics approval Due to the characteristics of the paper, no ethical approval is required.

Informed consent Since there are no pictures involving individuals, informed consent is not needed.

Conflict of interest Authors declare no conflicts of interest.

\section{References}

1. Gupta A, Madhavan MV, Sehgal K, Nair N, Mahajan S, Sehrawat TS, Bikdeli B, Ahluwalia N, Ausiello JC, Wan EY, Freedberg DE, Kirtane AJ, Parikh SA, Maurer MS, Nordvig AS, Accili D, Bathon JM, Mohan S, Bauer KA, Leon MB, Krumholz HM, Uriel N, Mehra MR, Elkind MSV, Stone GW, Schwartz A, Ho DD, Bilezikian JP, Landry DW. Extrapulmonary manifestations of COVID-19. Nat Med. 2020;26(7):1017-32. https://doi.org/10. 1038/s41591-020-0968-3.

2. Puig-Domingo M, Marazuela M, Yildiz BO, Giustina A. COVID19 and endocrine and metabolic diseases. An updated statement from the European Society of Endocrinology. Endocrine 2021;72(2):301-316. https://doi.org/10.1007/s12020-021-02734-w

3. Puig-Domingo M, Marazuela M, Giustina A. COVID-19 and endocrine diseases. A statement from the European Society of Endocrinology. Endocrine 2020;68(1):2-5. https://doi.org/10. 1007/s12020-020-02294-5

4. Zhou Y, Yang Q, Chi J, Dong B, Lv W, Shen L, Wang Y. Comorbidities and the risk of severe or fatal outcomes associated with coronavirus disease 2019: A systematic review and meta-analysis. Int J Infect Dis. 2020;99:47-56. https://doi.org/10.1016/j.ijid. 2020.07.029.

5. Frara S, Allora A, Castellino L, di Filippo L, Loli P, Giustina A. COVID-19 and the pituitary. Pituitary. 2021;24(3):465-81. https://doi.org/10.1007/s11102-021-01148-1.

6. Gasco V, Cambria V, Bioletto F, Ghigo E, Grottoli S. Traumatic Brain Injury as Frequent Cause of Hypopituitarism and Growth 
Hormone Deficiency: Epidemiology, Diagnosis, and Treatment. Front Endocrinol (Lausanne). 2021;12: 634415. https://doi.org/ 10.3389/fendo.2021.634415.

7. Fleseriu M, Hashim IA, Karavitaki N, Melmed S, Murad MH, Salvatori R, Samuels MH. Hormonal Replacement in Hypopituitarism in Adults: An Endocrine Society Clinical Practice Guideline. J Clin Endocrinol Metab. 2016;101(11):3888-921. https:// doi.org/10.1210/jc.2016-2118.

8. Nielsen EH, Lindholm J, Laurberg P. Excess mortality in women with pituitary disease: a meta-analysis. Clin Endocrinol (Oxf). 2007;67(5):693-7. https://doi.org/10.1111/j.1365-2265.2007. 02947.x.

9. Erfurth EM. Update in mortality in GH-treated patients. J Clin Endocrinol Metab. 2013;98(11):4219-26. https://doi.org/10. 1210/jc.2013-2415.

10. van Bunderen CC, van Nieuwpoort IC, Arwert LI, Heymans MW, Franken AA, Koppeschaar HP, van der Lely AJ, Drent ML. Does growth hormone replacement therapy reduce mortality in adults with growth hormone deficiency? Data from the Dutch National Registry of Growth Hormone Treatment in adults. J Clin Endocrinol Metab. 2011;96(10):3151-9. https://doi.org/10. 1210/jc.2011-1215.

11. Hamming I, Timens W, Bulthuis ML, Lely AT, Navis G, van Goor H. Tissue distribution of ACE2 protein, the functional receptor for SARS coronavirus. A first step in understanding SARS pathogenesis. J Pathol 2004;203(2):631-637. https://doi. org/10.1002/path.1570.

12. Mao L, Jin H, Wang M, Hu Y, Chen S, He Q, Chang J, Hong C, Zhou Y, Wang D, Miao X, Li Y, Hu B. Neurologic Manifestations of Hospitalized Patients With Coronavirus Disease 2019 in Wuhan. China JAMA Neurol. 2020;77(6):683-90. https://doi. org/10.1001/jamaneurol.2020.1127.

13. Conde Cardona G, Quintana Pajaro LD, Quintero Marzola ID, Ramos Villegas Y, Moscote Salazar LR. Neurotropism of SARSCoV 2: Mechanisms and manifestations. J Neurol Sci. 2020;412: 116824. https://doi.org/10.1016/j.jns.2020.116824.

14. Han T, Kang J, Li G, Ge J, Gu J. Analysis of 2019-nCoV receptor ACE2 expression in different tissues and its significance study. Ann Transl Med. 2020;8(17):1077. https://doi.org/10.21037/ atm-20-4281.

15. Ding Y, He L, Zhang Q, Huang Z, Che X, Hou J, Wang H, Shen H, Qiu L, Li Z, Geng J, Cai J, Han H, Li X, Kang W, Weng D, Liang P, Jiang S. Organ distribution of severe acute respiratory syndrome (SARS) associated coronavirus (SARS-CoV) in SARS patients: implications for pathogenesis and virus transmission pathways. J Pathol. 2004;203(2):622-30. https://doi. org/10.1002/path.1560.

16. Li W, Moore MJ, Vasilieva N, Sui J, Wong SK, Berne MA, Somasundaran M, Sullivan JL, Luzuriaga K, Greenough TC, Choe H, Farzan M. Angiotensin-converting enzyme 2 is a functional receptor for the SARS coronavirus. Nature. 2003;426(6965):450-4. https://doi.org/10.1038/nature02145.

17. Walls AC, Park YJ, Tortorici MA, Wall A, McGuire AT, Veesler D. Structure, Function, and Antigenicity of the SARSCoV-2 Spike Glycoprotein. Cell. 2020;183(6):1735. https://doi. org/10.1016/j.cell.2020.11.032.

18. Chen N, Zhou M, Dong X, Qu J, Gong F, Han Y, Qiu Y, Wang J, Liu Y, Wei Y, Xia J, Yu T, Zhang X, Zhang L. Epidemiological and clinical characteristics of 99 cases of 2019 novel coronavirus pneumonia in Wuhan, China: a descriptive study. Lancet. 2020;395(10223):507-13. https://doi.org/10.1016/ S0140-6736(20)30211-7.

19. Bilezikian JP, Bikle D, Hewison M, Lazaretti-Castro M, Formenti AM, Gupta A, Madhavan MV, Nair N, Babalyan V, Hutchings N, Napoli N, Accili D, Binkley N, Landry DW, Giustina A. MECHANISMS IN ENDOCRINOLOGY: Vitamin D and COVID-19.
Eur J Endocrinol. 2020;183(5):R133-47. https://doi.org/10.1530/ EJE-20-0665.

20. Brandi ML, Giustina A. Sexual Dimorphism of Coronavirus 19 Morbidity and Lethality. Trends Endocrinol Metab. 2020;31(12):918-27. https://doi.org/10.1016/j.tem.2020.09. 003.

21. Marazuela M, Giustina A, Puig-Domingo M. Endocrine and metabolic aspects of the COVID-19 pandemic. Rev Endocr Metab Disord. 2020;21(4):495-507. https://doi.org/10.1007/ s11154-020-09569-2.

22. Giustina A, Formenti A. Re: Preventing a covid-19 pandemic Can high prevalence of severe hypovitaminosis D play a role in the high impact of Covid infection in Italy? BMJ. 2020;368: m810. https://doi.org/10.1136/bmj.m810.

23. Lima-Martinez MM, Carrera Boada C, Madera-Silva MD, Marin W, Contreras M. COVID-19 and diabetes: A bidirectional relationship. Clin Investig Arterioscler. 2020. https://doi.org/10. 1016/j.arteri.2020.10.001.

24. Coppelli A, Giannarelli R, Aragona M, Penno G, Falcone M, Tiseo G, Ghiadoni L, Barbieri G, Monzani F, Virdis A, Menichetti F, Del Prato S, Pisa C-SG. Hyperglycemia at Hospital Admission Is Associated With Severity of the Prognosis in Patients Hospitalized for COVID-19: The Pisa COVID-19 Study. Diabetes Care. 2020;43(10):2345-8. https://doi.org/10.2337/dc20-1380.

25. Cariou B, Hadjadj S, Wargny M, Pichelin M, Al-Salameh A, Allix I, Amadou C, Arnault G, Baudoux F, Bauduceau B, Borot S, Bourgeon-Ghittori M, Bourron O, Boutoille D, Cazenave-Roblot F, Chaumeil C, Cosson E, Coudol S, Darmon P, Disse E, DucetBoiffard A, Gaborit B, Joubert M, Kerlan V, Laviolle B, Marchand L, Meyer L, Potier L, Prevost G, Riveline JP, Robert R, Saulnier PJ, Sultan A, Thebaut JF, Thivolet C, Tramunt B, Vatier C, Roussel $\mathrm{R}$, Gautier JF, Gourdy P, Investigators C. Phenotypic characteristics and prognosis of inpatients with COVID-19 and diabetes: the CORONADO study. Diabetologia. 2020;63(8):1500-15. https:// doi.org/10.1007/s00125-020-05180-x.

26. Apicella M, Campopiano MC, Mantuano M, Mazoni L, Coppelli A, Del Prato S. COVID-19 in people with diabetes: understanding the reasons for worse outcomes. Lancet Diabetes Endocrinol. 2020;8(9):782-92. https://doi.org/10.1016/S2213-8587(20) 30238-2.

27. Moller N, Jorgensen JO. Effects of growth hormone on glucose, lipid, and protein metabolism in human subjects. Endocr Rev. 2009;30(2):152-77. https://doi.org/10.1210/er.2008-0027.

28. Johansson JO, Fowelin J, Landin K, Lager I, Bengtsson BA. Growth hormone-deficient adults are insulin-resistant. Metabolism. 1995;44(9):1126-9. https://doi.org/10.1016/0026-0495(95) 90004-7.

29. Salomon F, Cuneo RC, Hesp R, Sonksen PH. The effects of treatment with recombinant human growth hormone on body composition and metabolism in adults with growth hormone deficiency. N Engl J Med. 1989;321(26):1797-803. https://doi.org/10.1056/ NEJM198912283212605.

30. Fowelin J, Attvall S, Lager I, Bengtsson BA. Effects of treatment with recombinant human growth hormone on insulin sensitivity and glucose metabolism in adults with growth hormone deficiency. Metabolism. 1993;42(11):1443-7. https://doi.org/10. 1016/0026-0495(93)90197-v.

31. Gao M, Piernas C, Astbury NM, Hippisley-Cox J, O'Rahilly $\mathrm{S}$, Aveyard P, Jebb SA. Associations between body-mass index and COVID-19 severity in 6.9 million people in England: a prospective, community-based, cohort study. Lancet Diabetes Endocrinol. 2021. https://doi.org/10.1016/S2213-8587(21)00089-9

32. Simonnet A, Chetboun M, Poissy J, Raverdy V, Noulette J, Duhamel A, Labreuche J, Mathieu D, Pattou F, Jourdain M, Licorn, the Lille C, Obesity study g, . High Prevalence of Obesity in Severe Acute Respiratory Syndrome Coronavirus-2 
(SARS-CoV-2) Requiring Invasive Mechanical Ventilation. Obesity (Silver Spring). 2020;28(7):1195-9. https://doi.org/10. 1002/oby.22831.

33. Huang Y, Lu Y, Huang YM, Wang M, Ling W, Sui Y, Zhao HL. Obesity in patients with COVID-19: a systematic review and meta-analysis. Metabolism. 2020;113: 154378. https://doi.org/ 10.1016/j.metabol.2020.154378.

34. Di Filippo L, De Lorenzo R, Cinel E, Falbo E, Ferrante M, Cilla M, Martinenghi S, Vitali G, Bosi E, Giustina A, Rovere-Querini P, Conte $\mathrm{C}$. Weight trajectories and abdominal adiposity in COVID19 survivors with overweight/obesity. Int J Obes (Lond). 2021. https://doi.org/10.1038/s41366-021-00861-y.

35. Mazziotti G, Formenti AM, Frara S, Maffezzoni F, Doga M, Giustina A. Diabetes in Cushing Disease. Curr Diab Rep. 2017;17(5):32. https://doi.org/10.1007/s11892-017-0860-9.

36. Frara S, Maffezzoni F, Mazziotti G, Giustina A. Current and Emerging Aspects of Diabetes Mellitus in Acromegaly. Trends Endocrinol Metab. 2016;27(7):470-83. https://doi.org/10.1016/j. tem.2016.04.014.

37. Gazzaruso C, Gola M, Karamouzis I, Giubbini R, Giustina A. Cardiovascular risk in adult patients with growth hormone (GH) deficiency and following substitution with $\mathrm{GH}$-an update. J Clin Endocrinol Metab. 2014;99(1):18-29. https://doi.org/10.1210/jc. 2013-2394.

38. Doga M, Bonadonna S, Gola M, Mazziotti G, Giustina A. Growth hormone deficiency in the adult. Pituitary. 2006;9(4):305-11. https://doi.org/10.1007/s11102-006-0410-y.

39. Buicu AL, Cernea S, Benedek I, Buicu CF, Benedek T. Systemic Inflammation and COVID-19 Mortality in Patients with Major Noncommunicable Diseases: Chronic Coronary Syndromes, Diabetes and Obesity. J Clin Med 2021;10(8). https://doi.org/ 10.3390/jcm10081545.

40. Vergara P, Rossi L, Biagi A, Falasconi G, Pannone L, Zanni A, Sticozzi C, Comastri G, Gandolfi S, Godino C, Malagoli A, Villani GQ. Role of comorbidities on the mortality in patients with SARS-CoV-2 infection: an Italian cohort study. Minerva Med. 2021. https://doi. org/10.23736/S0026-4806.21.07187-1.

41. Aleksova A, Gagno G, Sinagra G, Beltrami AP, Janjusevic M, Ippolito G, Zumla A, Fluca AL, Ferro F. Effects of SARS-CoV-2 on Cardiovascular System: The Dual Role of Angiotensin-Converting Enzyme 2 (ACE2) as the Virus Receptor and Homeostasis Regulator-Review. Int J Mol Sci 2021;22(9). https://doi.org/10. 3390/ijms22094526

42. Mach F, Baigent C, Catapano AL, Koskinas KC, Casula M, Badimon L, Chapman MJ, De Backer GG, Delgado V, Ference BA, Graham IM, Halliday A, Landmesser U, Mihaylova B, Pedersen TR, Riccardi G, Richter DJ, Sabatine MS, Taskinen MR, Tokgozoglu L, Wiklund O, Group ESCSD. 2019 ESC/EAS Guidelines for the management of dyslipidaemias: lipid modification to reduce cardiovascular risk. Eur Heart J. 2020;41(1):111-88. https://doi.org/10.1093/eurheartj/ ehz455.

43. Abdu TA, Neary R, Elhadd TA, Akber M, Clayton RN. Coronary risk in growth hormone deficient hypopituitary adults: increased predicted risk is due largely to lipid profile abnormalities. Clin Endocrinol (Oxf). 2001;55(2):209-16. https://doi.org/10.1046/j. 1365-2265.2001.01320.x.

44. Sesmilo G, Biller BM, Llevadot J, Hayden D, Hanson G, Rifai $\mathrm{N}$, Klibanski A. Effects of growth hormone administration on inflammatory and other cardiovascular risk markers in men with growth hormone deficiency. A randomized, controlled clinical trial. Ann Intern Med 2000;133(2):111-122. https://doi.org/10. 7326/0003-4819-133-2-200007180-00010

45. Wu C, Chen X, Cai Y, Xia J, Zhou X, Xu S, Huang H, Zhang L, Zhou X, Du C, Zhang Y, Song J, Wang S, Chao Y, Yang Z, Xu J, Zhou X, Chen D, Xiong W, Xu L, Zhou F, Jiang J, Bai C, Zheng J, Song Y. Risk Factors Associated With Acute Respiratory
Distress Syndrome and Death in Patients With Coronavirus Disease 2019 Pneumonia in Wuhan. China JAMA Intern Med. 2020;180(7):934-43. https://doi.org/10.1001/jamainternmed. 2020.0994.

46. Napoli R, Guardasole V, Angelini V, D'Amico F, Zarra E, Matarazzo M, Sacca L. Acute effects of growth hormone on vascular function in human subjects. J Clin Endocrinol Metab. 2003;88(6):2817-20. https://doi.org/10.1210/jc.2003-030144.

47. Donath MY, Sutsch G, Yan XW, Piva B, Brunner HP, Glatz Y, Zapf J, Follath F, Froesch ER, Kiowski W. Acute cardiovascular effects of insulin-like growth factor I in patients with chronic heart failure. J Clin Endocrinol Metab. 1998;83(9):3177-83. https://doi.org/10.1210/jcem.83.9.5122.

48. Boger RH, Skamira C, Bode-Boger SM, Brabant G, von zur Muhlen A, Frolich JC. Nitric oxide may mediate the hemodynamic effects of recombinant growth hormone in patients with acquired growth hormone deficiency. A double-blind, placebo-controlled study. J Clin Invest 1996;98(12):2706-2713. https://doi.org/10.1172/ JCI119095

49. Rosen T, Eden S, Larson G, Wilhelmsen L, Bengtsson BA. Cardiovascular risk factors in adult patients with growth hormone deficiency. Acta Endocrinol (Copenh). 1993;129(3):195-200. https://doi.org/10.1530/acta.0.1290195.

50. Leon-Pedroza JI, Rodriguez-Cortes O, Flores-Mejia R, GaonaAguas CV, Gonzalez-Chavez A. Impact of metabolic syndrome in the clinical outcome of disease by SARS-COV-2 in Mexican population. Arch Med Res. 2021. https://doi.org/10.1016/j.arcmed.2021.04.001.

51. di Filippo L, Formenti AM, Doga M, Pedone E, Rovere-Querini P, Giustina A. Radiological Thoracic Vertebral Fractures are Highly Prevalent in COVID-19 and Predict Disease Outcomes. J Clin Endocrinol Metab. 2021;106(2):e602-14. https://doi.org/ 10.1210/clinem/dgaa738.

52. Mazziotti G, Baracca M, Doga M, Porcelli T, Vescovi PP, Giustina A. Prevalence of thoracic vertebral fractures in hospitalized elderly patients with heart failure. Eur J Endocrinol. 2012;167(6):865-72. https://doi.org/10.1530/EJE-12-0566.

53. Cellini M, Piccini S, Ferrante G, Carrone F, Olivetti R, Cicorella N, Aroldi M, Pini D, Centanni M, Lania AG, Mazziotti G. Secondary hyperparathyroidism and thoracic vertebral fractures in heart failure middle-aged patients: a 3-year prospective study. J Endocrinol Invest. 2020;43(11):1561-9. https://doi.org/10.1007/ s40618-020-01237-1.

54. Watanabe R, Shiraki M, Saito M, Okazaki R, Inoue D. Restrictive pulmonary dysfunction is associated with vertebral fractures and bone loss in elderly postmenopausal women. Osteoporos Int. 2018;29(3):625-33. https://doi.org/10.1007/s00198-017-4337-0.

55. Krege JH, Kendler D, Krohn K, Genant H, Alam J, Berclaz PY, Coffey B, Loghin C. Relationship Between Vertebral Fracture Burden, Height Loss, and Pulmonary Function in Postmenopausal Women With Osteoporosis. J Clin Densitom. 2015;18(4):506-11. https://doi.org/10.1016/j.jocd.2015.02.004.

56. Kim B, Kim J, Jo YH, Kang SH, Lee YJ, Lee JH, Hwang JE, Park MJ, Lee S. Risk of Pneumonia After Vertebral Compression Fracture in Women With Low Bone Density: A PopulationBased Study. Spine (Phila Pa 1976) 2018;43(14):E830-E835. https://doi.org/10.1097/BRS.0000000000002536

57. Mazziotti G, Frara S, Giustina A. Pituitary Diseases and Bone. Endocr Rev. 2018;39(4):440-88. https://doi.org/10.1210/er. 2018-00005.

58. Bravenboer N, Holzmann P, de Boer H, Blok GJ, Lips P. Histomorphometric analysis of bone mass and bone metabolism in growth hormone deficient adult men. Bone. 1996;18(6):551-7. https://doi.org/10.1016/8756-3282(96)00069-5.

59. Mormando M, Chiloiro S, Bianchi A, Giampietro A, Angelini F, Tartaglione L, Nasto L, Milardi D, Formenti AM, Giustina A, De 
Marinis L. Growth hormone receptor isoforms and fracture risk in adult-onset growth hormone-deficient patients. Clin Endocrinol (Oxf). 2016;85(5):717-24. https://doi.org/10.1111/cen.13161.

60. Mazziotti G, Doga M, Frara S, Maffezzoni F, Porcelli T, Cerri L, Maroldi R, Giustina A. Incidence of morphometric vertebral fractures in adult patients with growth hormone deficiency. Endocrine. 2016;52(1):103-10. https://doi.org/10.1007/ s12020-015-0738-z.

61. Christ-Crain M, Hoorn EJ, Sherlock M, Thompson CJ, Wass JAH. ENDOCRINOLOGY IN THE TIME OF COVID-19: Management of diabetes insipidus and hyponatraemia. Eur J Endocrinol. 2020;183(1):G9-15. https://doi.org/10.1530/ EJE-20-0338.

62. Darmon M, Timsit JF, Francais A, Nguile-Makao M, Adrie C, Cohen Y, Garrouste-Orgeas M, Goldgran-Toledano D, Dumenil AS, Jamali S, Cheval C, Allaouchiche B, Souweine B, Azoulay E. Association between hypernatraemia acquired in the ICU and mortality: a cohort study. Nephrol Dial Transplant. 2010;25(8):25105. https://doi.org/10.1093/ndt/gfq067.

63. Briet C, Salenave S, Bonneville JF, Laws ER, Chanson P. Pituitary Apoplexy. Endocr Rev. 2015;36(6):622-45. https://doi.org/ 10.1210/er.2015-1042.

64. Barkhoudarian G, Kelly DF. Pituitary Apoplexy. Neurosurg Clin N Am. 2019;30(4):457-63. https://doi.org/10.1016/j.nec.2019. 06.001 .

65. Doglietto F, Costi E, Villaret AB, Mardighian D, Fontanella MM, Giustina A. New oral anticoagulants and pituitary apoplexy. Pituitary. 2016;19(2):232-4. https://doi.org/10.1007/ s11102-014-0616-3.

66. Casanueva FF, Molitch ME, Schlechte JA, Abs R, Bonert V, Bronstein MD, Brue T, Cappabianca P, Colao A, Fahlbusch R, Fideleff H, Hadani M, Kelly P, Kleinberg D, Laws E, Marek J, Scanlon M, Sobrinho LG, Wass JA, Giustina A. Guidelines of the Pituitary Society for the diagnosis and management of prolactinomas. Clin Endocrinol (Oxf). 2006;65(2):265-73. https:// doi.org/10.1111/j.1365-2265.2006.02562.x.

67. Mancini T, Casanueva FF, Giustina A. Hyperprolactinemia and prolactinomas. Endocrinol Metab Clin North Am. 2008;37(1):67-99, viii. https://doi.org/10.1016/j.ecl.2007.10.013

68. Bhoelan S, Langerak T, Noack D, van Schinkel L, van Nood E, van Gorp ECM, Rockx B, Goeijenbier M. Hypopituitarism after Orthohantavirus Infection: What is Currently Known? Viruses. 2019;11(4). https://doi.org/10.3390/v11040340

69. Tan SK, Seow CJ, Tan E, Chau YP, Dalan R. Pituitary apoplexy secondary to thrombocytopenia due to dengue hemorrhagic fever: a case report and review of the literature. Endocr Pract. 2014;20(4):e58-64. https://doi.org/10.4158/EP13319.CR.

70. Chan JL, Gregory KD, Smithson SS, Naqvi M, Mamelak AN. Pituitary apoplexy associated with acute COVID-19 infection and pregnancy. Pituitary. 2020;23(6):716-20. https://doi.org/10. 1007/s11102-020-01080-w.

71. Ghosh R, Roy D, Roy D, Mandal A, Dutta A, Naga D, BenitoLeon J. A Rare Case of SARS-CoV-2 Infection Associated With Pituitary Apoplexy Without Comorbidities. J Endocr Soc. 2021;5(3):bvaa203. https://doi.org/10.1210/jendso/bvaa203

72. Santos C, Filho L, Santos CAT, Neill JS, Vale HF, Kurnutala LN. Pituitary tumor resection in a patient with SARS-CoV-2 (COVID-19) infection. A case report and suggested airway management guidelines. Braz J Anesthesiol. 2020;70(2):165-170. https://doi.org/10.1016/j.bjane.2020.05.003

73. Solorio-Pineda S, Almendarez-Sanchez CA, Tafur-Grandett AA, Ramos-Martinez GA, Huato-Reyes R, Ruiz-Flores MI, SosaNajera A. Pituitary macroadenoma apoplexy in a severe acute respiratory syndrome-coronavirus-2-positive testing: Causal or casual? Surg Neurol Int. 2020;11:304. https://doi.org/10.25259/ SNI_305_2020.
74. Chigr F, Merzouki M, Najimi M. Autonomic Brain Centers and Pathophysiology of COVID-19. ACS Chem Neurosci. 2020;11(11):1520-2. https://doi.org/10.1021/acschemneuro. $0 \mathrm{c} 00265$.

75. Fleseriu M, Dekkers OM, Karavitaki N. Endocrinology in the time of COVID-19: Management of pituitary tumours. Eur J Endocrinol. 2020;183(1):G17-23. https://doi.org/10.1530/ EJE-20-0473.

76. Bordes SJ, Phang-Lyn S, Najera E, Borghei-Razavi H, Adada B. Pituitary Apoplexy Attributed to COVID-19 Infection in the Absence of an Underlying Macroadenoma or Other Identifiable Cause. Cureus. 2021;13(2): e13315. https://doi.org/10.7759/ cureus.13315.

77. Quinkler M, Ekman B, Zhang P, Isidori AM, Murray RD, Investigators E-A. Mortality data from the European Adrenal Insufficiency Registry-Patient characterization and associations. Clin Endocrinol (Oxf). 2018;89(1):30-5. https://doi.org/10.1111/cen. 13609.

78. Bancos I, Hazeldine J, Chortis V, Hampson P, Taylor AE, Lord JM, Arlt W. Primary adrenal insufficiency is associated with impaired natural killer cell function: a potential link to increased mortality. Eur J Endocrinol. 2017;176(4):471-80. https://doi.org/ 10.1530/EJE-16-0969.

79. Stewart PM, Biller BM, Marelli C, Gunnarsson C, Ryan MP, Johannsson G. Exploring Inpatient Hospitalizations and Morbidity in Patients With Adrenal Insufficiency. J Clin Endocrinol Metab. 2016;101(12):4843-50. https://doi.org/10.1210/jc. 2016-2221.

80. Ebrahimi F, Widmer A, Wagner U, Mueller B, Schuetz P, Christ-Crain M, Kutz A. Association of adrenal insufficiency with patient-oriented health-care outcomes in adult medical inpatients. Eur J Endocrinol. 2019;181(6):701-9. https://doi.org/10. 1530/EJE-19-0469.

81. Tresoldi AS, Sumilo D, Perrins M, Toulis KA, Prete A, Reddy N, Wass JAH, Arlt W, Nirantharakumar K. Increased infection risk in addison's disease and congenital adrenal hyperplasia. J Clin Endocrinol Metab. 2020;105(2). https://doi.org/10.1210/clinem/ dgz006

82. Iwasaku M, Tanaka S, Shinzawa M, Kawakami K. Impact of underlying chronic adrenal insufficiency on clinical course of hospitalized patients with adrenal crisis: A nationwide cohort study. Eur J Intern Med. 2019;64:24-8. https://doi.org/10.1016/j. ejim.2019.04.001.

83. Frara S, Rodriguez-Carnero G, Formenti AM, Martinez-Olmos MA, Giustina A, Casanueva FF. Pituitary Tumors Centers of Excellence. Endocrinol Metab Clin North Am. 2020;49(3):55364. https://doi.org/10.1016/j.ecl.2020.05.010.

84. Arlt W, Baldeweg SE, Pearce SHS, Simpson HL. ENDOCRINOLOGY IN THE TIME OF COVID-19: Management of adrenal insufficiency. Eur J Endocrinol. 2020;183(1):G25-32. https:// doi.org/10.1530/EJE-20-0361.

85. Mazziotti G, Formenti AM, Frara S, Roca E, Mortini P, Berruti A, Giustina A. MANAGEMENT OF ENDOCRINE DISEASE: Risk of overtreatment in patients with adrenal insufficiency: current and emerging aspects. Eur J Endocrinol. 2017;177(5):R23148. https://doi.org/10.1530/EJE-17-0154.

86. Ko JJ, Wu C, Mehta N, Wald-Dickler N, Yang W, Qiao R. A Comparison of Methylprednisolone and Dexamethasone in Intensive Care Patients With COVID-19. J Intensive Care Med. 2021:885066621994057. https://doi.org/10.1177/ 0885066621994057

87. Zhang Y, Hu S, Wang J, Xue Z, Wang C, Wang N. Dexamethasone inhibits SARS-CoV-2 spike pseudotyped virus viropexis by binding to ACE2. Virology. 2021;554:83-8. https://doi.org/10. 1016/j.virol.2020.12.001. 
88. Carosi G, Morelli V, Del Sindaco G, Serban AL, Cremaschi A, Frigerio S, Rodari G, Profka E, Indirli R, Mungari R, Resi V, Orsi E, Ferrante E, Dolci A, Giavoli C, Arosio M, Mantovani G. Adrenal insufficiency at the time of COVID-19: a retrospective study in patients referring to a tertiary centre. J Clin Endocrinol Metab. 2020. https://doi.org/10.1210/clinem/dgaa793.

89. Leow MK, Kwek DS, Ng AW, Ong KC, Kaw GJ, Lee LS. Hypocortisolism in survivors of severe acute respiratory syndrome (SARS). Clin Endocrinol (Oxf). 2005;63(2):197-202. https://doi. org/10.1111/j.1365-2265.2005.02325.x.

90. Alzahrani AS, Mukhtar N, Aljomaiah A, Aljamei H, Bakhsh A, Alsudani N, Elsayed T, Alrashidi N, Fadel R, Alqahtani E, Raef H, Butt MI, Sulaiman O. The Impact of COVID-19 Viral Infection on the Hypothalamic-Pituitary-Adrenal Axis. Endocr Pract. 2021;27(2):83-9. https://doi.org/10.1016/j.eprac.2020.10.014.

91. Martino M, Aboud N, Cola MF, Giancola G, Ciarloni A, Salvio G, Arnaldi G. Impact of COVID-19 pandemic on psychophysical stress in patients with adrenal insufficiency: the CORTI-COVID study. J Endocrinol Invest. 2021;44(5):1075-84. https://doi.org/ 10.1007/s40618-020-01422-2.

92. Graf A, Marcus HJ, Baldeweg SE. The direct and indirect impact of the COVID-19 pandemic on the care of patients with pituitary disease: a cross sectional study. Pituitary. 2021;24(2):262-8. https://doi.org/10.1007/s11102-020-01106-3.

93. Li D, Suresh M, Abbondanza T, Vaidya A, Bancos I. The Impact of the COVID-19 Pandemic on Self-Reported Outcomes in Patients With Adrenal Insufficiency. J Clin Endocrinol Metab. 2021. https://doi.org/10.1210/clinem/dgab334.

94. Loli P, Frara S, Pasquali R, Di Filippo L, Rovere-Querini P, Giustina A. COVID-19 and hypopituitarism. Experience from an endocrine center in a high-impact area. Endocrine Abstract. 2020;70:AEP1075. https://doi.org/10.1530/endoabs.70.AEP1075

95. Beretta F, Dassie F, Parolin M, Boscari F, Barbot M, Busetto L, Mioni R, De Carlo E, Scaroni C, Fallo F, Vettor R, Maffei P. Practical Considerations for the Management of Cushing's Disease and COVID-19: A Case Report. Front Endocrinol (Lausanne). 2020;11:554. https://doi.org/10.3389/fendo.2020.00554.

96. Isidori AM, Arnaldi G, Boscaro M, Falorni A, Giordano C, Giordano R, Pivonello R, Pofi R, Hasenmajer V, Venneri MA, Sbardella E, Simeoli C, Scaroni C, Lenzi A. COVID-19 infection and glucocorticoids: update from the Italian Society of Endocrinology Expert Opinion on steroid replacement in adrenal insufficiency. J Endocrinol Invest. 2020;43(8):1141-7. https://doi.org/ 10.1007/s40618-020-01266-w.

97. Fleseriu M, Buchfelder M, Cetas JS, Fazeli PK, Mallea-Gil SM, Gurnell M, McCormack A, Pineyro MM, Syro LV, Tritos NA, Marcus HJ. Pituitary society guidance: pituitary disease management and patient care recommendations during the COVID-19 pandemic-an international perspective. Pituitary. 2020;23(4):32737. https://doi.org/10.1007/s11102-020-01059-7.

98. Baldeweg SE, Ball S, Brooke A, Gleeson HK, Levy MJ, Prentice M, Wass J, Society for Endocrinology Clinical C. SOCIETY FOR ENDOCRINOLOGY CLINICAL GUIDANCE: Inpatient management of cranial diabetes insipidus. Endocr Connect. 2018;7(7):G8-11. https://doi.org/10.1530/EC-18-0154.

99. Raimondi F, Novelli L, Ghirardi A, Russo FM, Pellegrini D, Biza R, Trapasso R, Giuliani L, Anelli M, Amoroso M, Allegri C, Imeri G, Sanfilippo C, Comandini S, Hila E, Manesso L, Gandini L, Mandelli P, Monti M, Gori M, Senni M, Lorini FL, Rizzi M, Barbui T, Paris L, Rambaldi A, Cosentini R, Guagliumi G, Cesa S, Colledan M, Sessa M, Masciulli A, Gavazzi A, Buoro S, Remuzzi G, Ruggenenti P, Callegaro A, Gianatti A, Farina C, Bellasi A, Sironi S, Fagiuoli S, Di Marco F, Group HPGC-S. Covid-19 and gender: lower rate but same mortality of severe disease in women-an observational study. BMC Pulm Med. 2021;21(1):96. https://doi.org/10.1186/ s12890-021-01455-0.
100. Corona G, Rastrelli G, Isidori AM, Pivonello R, Bettocchi C, Reisman Y, Sforza A, Maggi M. Erectile dysfunction and cardiovascular risk: a review of current findings. Expert Rev Cardiovasc Ther. 2020;18(3):155-64. https://doi.org/10.1080/ 14779072.2020 .1745632$.

101. Ramirez R, Pedro-Botet J, Garcia M, Corbella E, Merino J, Zambon D, Corbella X, Pinto X, de Unitats X, de Lipids i Arteriosclerosi Investigators G. Erectile dysfunction and cardiovascular risk factors in a Mediterranean diet cohort. Intern Med J. 2016;46(1):52-6. https://doi.org/10.1111/imj.12937.

102. Sansone A, Mollaioli D, Ciocca G, Colonnello E, Limoncin E, Balercia G, Jannini EA. "Mask up to keep it up": Preliminary evidence of the association between erectile dysfunction and COVID-19. Andrology. 2021. https://doi.org/10.1111/andr. 13003.

103. Schroeder M, Tuku B, Jarczak D, Nierhaus A, Bai T, Jacobsen H, Zickler M, Muller Z, Stanelle-Bertram S, Meinhardt A, Aberle J, Kluge S, Gabriel G. The majority of male patients with COVID19 present low testosterone levels on admission to Intensive Care in Hamburg, Germany: a retrospective cohort study. medRxiv 2020;(20073817)05-07. https://doi.org/10.1101/2020.05.07. 20073817

104. Rastrelli G, Di Stasi V, Inglese F, Beccaria M, Garuti M, Di Costanzo D, Spreafico F, Greco GF, Cervi G, Pecoriello A, Magini A, Todisco T, Cipriani S, Maseroli E, Corona G, Salonia A, Lenzi A, Maggi M, De Donno G, Vignozzi L. Low testosterone levels predict clinical adverse outcomes in SARS-CoV-2 pneumonia patients. Andrology. 2021;9(1):88-98. https://doi.org/10.1111/andr.12821.

105. Mohamed MS, Moulin TC, Schioth HB. Sex differences in COVID-19: the role of androgens in disease severity and progression. Endocrine. 2021;71(1):3-8. https://doi.org/10.1007/ s12020-020-02536-6.

106. Wambier CG, Vano-Galvan S, McCoy J, Gomez-Zubiaur A, Herrera S, Hermosa-Gelbard A, Moreno-Arrones OM, JimenezGomez N, Gonzalez-Cantero A, Fonda-Pascual P, SeguradoMiravalles G, Shapiro J, Perez-Garcia B, Goren A. Androgenetic alopecia present in the majority of patients hospitalized with COVID-19: The "Gabrin sign." J Am Acad Dermatol. 2020;83(2):680-2. https://doi.org/10.1016/j.jaad.2020.05.079.

107. Goren A, Vano-Galvan S, Wambier CG, McCoy J, Gomez-Zubiaur A, Moreno-Arrones OM, Shapiro J, Sinclair RD, Gold MH, Kovacevic M, Mesinkovska NA, Goldust M, Washenik K. A preliminary observation: Male pattern hair loss among hospitalized COVID-19 patients in Spain - A potential clue to the role of androgens in COVID-19 severity. J Cosmet Dermatol. 2020;19(7):1545-7. https://doi.org/10.1111/jocd. 13443.

108. Montopoli M, Zumerle S, Vettor R, Rugge M, Zorzi M, Catapano CV, Carbone GM, Cavalli A, Pagano F, Ragazzi E, Prayer-Galetti $\mathrm{T}$, Alimonti A. Androgen-deprivation therapies for prostate cancer and risk of infection by SARS-CoV-2: a population-based study (N = 4532). Ann Oncol. 2020;31(8):1040-5. https://doi.org/10.1016/j. annonc.2020.04.479.

109. Formenti AM, Dalla Volta A, di Filippo L, Berruti A, Giustina A. Effects of Medical Treatment of Prostate Cancer on Bone Health. Trends Endocrinol Metab. 2021;32(3):135-58. https://doi.org/10. 1016/j.tem.2020.12.004.

110. Vaira LA, Salzano G, Deiana G, De Riu G. Anosmia and Ageusia: Common Findings in COVID-19 Patients. Laryngoscope. 2020;130(7):1787. https://doi.org/10.1002/lary.28692.

111. Dolatshahi M, Sabahi M, Aarabi MH. Pathophysiological Clues to How the Emergent SARS-CoV-2 Can Potentially Increase the Susceptibility to Neurodegeneration. Mol Neurobiol. 2021;58(5):2379-94. https://doi.org/10.1007/s12035-020-02236-2.

112. Bertolo R, Cipriani C, Bove P. Anosmia and ageusia: a piece of the puzzle in the etiology of COVID-19-related transitory erectile 
dysfunction. J Endocrinol Invest. 2021;44(5):1123-4. https://doi. org/10.1007/s40618-021-01516-5.

113. Donini LM, Busetto L, Bauer JM, Bischoff S, Boirie Y, Cederholm T, Cruz-Jentoft AJ, Dicker D, Fruhbeck G, Giustina A, Gonzalez MC, Han HS, Heymsfield SB, Higashiguchi T, Laviano A, Lenzi A, Parrinello E, Poggiogalle E, Prado CM, Rodriguez JS, Rolland Y, Santini F, Siervo M, Tecilazich F, Vettor R, Yu J, Zamboni M, Barazzoni R. Critical appraisal of definitions and diagnostic criteria for sarcopenic obesity based on a systematic review. Clin Nutr. 2020;39(8):2368-88. https://doi.org/10.1016/j.clnu.2019.11.024.

114. Verhelst J, Mattsson AF, Camacho-Hubner C, Luger A, Abs R. The prevalence of the metabolic syndrome and associated cardiovascular complications in adult-onset GHD during GH replacement: a KIMS analysis. Endocr Connect. 2018;7(5):653-62. https://doi. org/10.1530/EC-18-0096.

115. Gola M, Bonadonna S, Doga M, Giustina A. Clinical review: Growth hormone and cardiovascular risk factors. J Clin Endocrinol Metab. 2005;90(3):1864-70. https://doi.org/10.1210/jc.2004-0545.

116. Lubrano C, Masi D, Risi R, Balena A, Watanabe M, Mariani S, Gnessi L. Is Growth Hormone Insufficiency the Missing Link Between Obesity, Male Gender, Age, and COVID-19 Severity? Obesity (Silver Spring). 2020;28(11):2038-9. https://doi.org/10. 1002/oby.23000.

117. Meazza C, Pagani S, Travaglino P, Bozzola M. Effect of growth hormone $(\mathrm{GH})$ on the immune system. Pediatr Endocrinol Rev. 2004;1(Suppl 3):490-5.

118. Miljic D, Miljic P, Doknic M, Pekic S, Stojanovic M, Cvijovic G, Micic D, Popovic V. Growth hormone replacement normalizes impaired fibrinolysis: new insights into endothelial dysfunction in patients with hypopituitarism and growth hormone deficiency. Growth Horm IGF Res. 2013;23(6):243-8. https://doi.org/10. 1016/j.ghir.2013.08.005.

119. Giavoli C, Profka E, Giancola N, Rodari G, Giacchetti F, Ferrante E, Arosio M, Mantovani G. Growth hormone therapy at the time of Covid-19 pandemic: adherence and drug supply issues. Eur J Endocrinol. 2020;183(4):L13-5. https://doi.org/10.1530/EJE-20-0481.

120. Bagnasco F, Di Iorgi N, Roveda A, Gallizia A, Haupt R, Maghnie M, Adherence Investigators Group. Prevalence and Correlates of Adherence in Children and Adolescents Treated with Growth Hormone: A Multicenter Italian Study. Endocr Pract. 2017;23(8):92941. https://doi.org/10.4158/EP171786.OR.

121. van Dommelen P, Koledova E, Wit JM. Effect of adherence to growth hormone treatment on 0-2 year catch-up growth in children with growth hormone deficiency. PLoS ONE. 2018;13(10): e0206009. https://doi.org/10.1371/journal.pone.0206009.

122. Rajevac H, Bachan M, Khan Z. Diabetes insipidus as a symptom of COVID-19 infection: case report. Chest. 2020;158(4):A2576. https://doi.org/10.1016/j.chest.2020.09.172.

123. Sheikh AB, Javed N, Sheikh AAE, Upadhyay S, Shekhar R. Diabetes Insipidus and Concomitant Myocarditis: A Late
Sequelae of COVID-19 Infection. J Investig Med High Impact Case Rep. 2021;9:2324709621999954. https://doi.org/10.1177/ 2324709621999954.

124. Ebrahimi F, Kutz A, Wagner U, Illigens B, Siepmann T, Schuetz P, Christ-Crain M, Mueller B, Christ ER. Excess Mortality Among Hospitalized Patients With Hypopituitarism-A Population-Based, Matched-Cohort Study. J Clin Endocrinol Metab. 2020;105(11). https://doi.org/10.1210/clinem/dgaa517

125. Polack FP, Thomas SJ, Kitchin N, Absalon J, Gurtman A, Lockhart S, Perez JL, Perez Marc G, Moreira ED, Zerbini C, Bailey R, Swanson KA, Roychoudhury S, Koury K, Li P, Kalina WV, Cooper D, Frenck RW, Jr., Hammitt LL, Tureci O, Nell H, Schaefer A, Unal S, Tresnan DB, Mather S, Dormitzer PR, Sahin U, Jansen KU, Gruber WC, Group CCT. Safety and Efficacy of the BNT162b2 mRNA Covid-19 Vaccine. N Engl J Med. 2020;383(27):2603-15. https://doi.org/10. 1056/NEJMoa2034577.

126. Baden LR, El Sahly HM, Essink B, Kotloff K, Frey S, Novak R, Diemert D, Spector SA, Rouphael N, Creech CB, McGettigan J, Khetan S, Segall N, Solis J, Brosz A, Fierro C, Schwartz H, Neuzil K, Corey L, Gilbert P, Janes H, Follmann D, Marovich M, Mascola J, Polakowski L, Ledgerwood J, Graham BS, Bennett H, Pajon R, Knightly C, Leav B, Deng W, Zhou H, Han S, Ivarsson M, Miller J, Zaks T, Group CS. Efficacy and Safety of the mRNA-1273 SARSCoV-2 Vaccine. N Engl J Med. 2021;384(5):403-16. https://doi. org/10.1056/NEJMoa2035389.

127. Deepak P, Kim W, Paley MA, Yang M, Carvidi AB, El-Qunni AA, Haile A, Huang K, Kinnett B, Liebeskind MJ, Liu Z, McMorrow LE, Paez D, Perantie DC, Schriefer RE, Sides SE, Thapa M, Gergely M, Abushamma S, Klebert M, Mitchell L, Nix D, Graf J, Taylor KE, Chahin S, Ciorba MA, Katz P, Matloubian M, O'Halloran JA, Presti RM, Wu GF, Whelan SPJ, Buchser WJ, Gensler LS, Nakamura MC, Ellebedy AH, Kim AHJ. Glucocorticoids and B Cell Depleting Agents Substantially Impair Immunogenicity of mRNA Vaccines to SARS-CoV-2. 2021 medRxiv. https://doi.org/10.1101/2021.04. 05.21254656

128. Fairchok MP, Trementozzi DP, Carter PS, Regnery HL, Carter ER. Effect of prednisone on response to influenza virus vaccine in asthmatic children. Arch Pediatr Adolesc Med. 1998;152(12):1191-5. https://doi.org/10.1001/archpedi.152.12.1191.

129. Katznelson L, Gadelha M. Glucocorticoid use in patients with adrenal insufficiency following administration of the COVID-19 vaccine: a pituitary society statement. Pituitary. 2021. https://doi. org/10.1007/s11102-021-01130-x.

130. Fleseriu M. Pituitary Disorders and COVID-19, Reimagining Care: The Pandemic A Year and Counting. Front Endocrinol (Lausanne). 2021;12: 656025. https://doi.org/10.3389/fendo.2021.656025.

Publisher's Note Springer Nature remains neutral with regard to jurisdictional claims in published maps and institutional affiliations. 